\title{
Amenities, affordability, and housing vouchers
}

\author{
David S. Bieri'1,2,3 (iD | Casey J. Dawkins ${ }^{4,5}$
}

\begin{abstract}
${ }^{1}$ School of Public \& International Affairs, Virginia Tech, Blacksburg, Virginia

${ }^{2}$ Department of Economics, Virginia Tech, Blacksburg, Virginia

${ }^{3}$ Global Forum on Urban \& Regional Resilience, Virginia Tech, Blacksburg, Virginia

${ }^{4}$ School of Architecture, Planning \& Preservation, University of Maryland, College Park, Maryland

${ }^{5}$ National Center for Smart Growth, University of Maryland, College Park, Maryland

\section{Correspondence}

David S. Bieri, School of Public \&

International Affairs, Virginia Tech, 140

Otey St., Blacksburg, VA 24601-0113.

Email:bieri@vt.edu

We are grateful to the editor, Ed Coulson, and two anonymous referees for detailed guidance and valuable comments on earlier drafts of this paper. Several colleagues have provided helpful input on this research, including, without implicating, Lan Deng, Jonathan Levine, Kirk McClure, and participants at seminar and conference presentations at the Annual Meetings of the Association of Collegiate Schools of Planning, the Regional Science Association International, the Urban Affairs Associations, and the Urban Economics Association. We thank Natalia Kolesnikova for providing us with MSA-level return to education estimates. An earlier version of this paper circulated under the title "Housing Affordability with Local Wage and Price Variation." Bieri also acknowledges financial support from the University of Michigan's Graham Institute on Environmental Sustainability. The usual disclaimers apply.
\end{abstract}

\begin{abstract}
Against the background of an emerging rental affordability crisis, we examine how the standard rule that households should not spend more than $30 \%$ of their income on housing expenditures leads to inefficiencies in the context of federal low-income housing policy. We quantify how the current practice of locally indexing individual rent subsidies in the Housing Choice Voucher (HCV) program regardless of quality-of-life conditions implicitly incentivizes recipients to live in high-amenity areas. We also assess a novel scenario for housing policy reform that adjusts subsidies by the amenity expenditures of low-income households, permitting national HCV program coverage to increase.
\end{abstract}

\section{KEYWORDS}

amenity expenditures, housing affordability, housing choice vouchers, locational efficiency, quality of life

JEL CLASSIFICATION:

Q5, R2, R3

\section{1 | INTRODUCTION}

An unprecedented surge in U.S. rental demand over the decade since the housing crisis has raised the specter of a rental affordability crisis, the brunt of which is borne by the most vulnerable segment of low-income households who live in high-wage large metro areas. When defining housing affordability, policymakers have long relied on the standard rule

This is an open access article under the terms of the Creative Commons Attribution-NonCommercial-NoDerivs License, which permits use and distribution in any medium, provided the original work is properly cited, the use is non-commercial and no modifications or adaptations are made.

(C) 2018 The Authors. Journal of Regional Science published by Wiley Periodicals, Inc. 
of thumb that households should not spend more than $30 \%$ of their income on housing expenditures. In the United States, this "30\% rule" is used to determine the appropriate level of housing subsidies for federal programs such as the Housing Choice Voucher (HCV) program-the U.S. Department of Housing and Urban Development's (HUD) primary tool for meeting its legislative mandate to provide "a decent home and a suitable living environment for every American family" (American Housing Act, 1949, p. 413)-where housing assistance payments (HAPs) close the gap between a local payment standard and $30 \%$ of a qualifying household's income. ${ }^{1}$

In this paper, we examine how the " $30 \%$ rule" leads to potential inefficiencies and distortions in the context of federal low-income housing policy. Specifically, we quantify how the federal practice of indexing the generosity of individual rent subsidies in the HCV program regardless of local quality-of-life conditions implicitly incentivizes recipients to live in high-amenity areas. We begin by noting two common concerns about such a national threshold for defining housing affordability. First, some object to using the $30 \%$ housing cost-income ratio as the basis for HCV subsidy payments, because it combines both income and housing costs into a single metric. The idea that households should not spend more than any fixed percentage of their budget on housing implies that the income elasticity of housing demand is equal to one. Yet, this assumption is difficult to reconcile with the stylized facts of the demand for housing, which show that housing expenditure shares tend to fall as incomes rise. The housing cost burden approach also conflates issues of income inequality with spatial inefficiencies created by supply-side housing market constraints (Glaeser \& Gyourko, 2008; Hsieh \& Moretti, 2017). Second, some argue that major federal transfer and welfare programs should not automatically be tied to local price levels. ${ }^{2}$ While economists generally prefer demand-side subsidies to supply-side subsidies due to the greater degree of household choice enabled by the former, indexing housing subsidies to local price levels may thus only be justified under special conditions that have negative welfare consequences for low-income households. For example, local housing supply in high-amenity areas might be so inelastic that affordable housing opportunities for low-income households are being crowded out (e.g., Glaeser, 1998; Kaplow, 1996; Knoll \& Griffith, 2003).

We develop a version of the canonical spatial equilibrium model à la Rosen $(1979)$ and Roback $(1982,1988)$ to assess the conditions under which the current HCV program design can be considered problematic from a welfare perspective. In this setting, significant intermetropolitan differences in the housing cost-to-income ratio need not reflect local disparities in household well-being. Empirically, we then take our theoretical model to the data by providing the first quantitative estimates of the dollar value of nonmarket amenities reflected in current HCV subsidies while adjusting for household preference heterogeneity. ${ }^{3}$

Our estimates make several contributions to the literature on housing affordability and to the literature on interregional amenity capitalization effects. ${ }^{4}$ First, we calculate HAPs for participants in the HCV program and demonstrate that these subsidies are significantly related to metropolitan quality-of-life differentials. In 2000 , the reference year for our analysis, the average annual housing subsidy is $\$ 4,260$ which amounts to about $20 \%$ of the annual income for very low-income households. ${ }^{5}$ There are large regional variations in the average size of these subsidies, ranging from $\$ 3,915$

\footnotetext{
1 Under current HCV program rules, eligible low-income households receive subsidies sufficient to close the gap between $30 \%$ of household income and a local payment standard that is indexed to median metropolitan statistical area (MSA) rents. In addition to demand-side subsidies under the HCV program, HUD provides supply-side subsidies to low-income households through public housing and various project-based assistance programs. The subsidies that these programs provide are not an entitlement. Typically, the number of low-income households eligible for assistance far exceeds the number of subsidized units and vouchers that is available. In the year 2000 , HCV program expenditure amounted to around $\$ 9$ billion, covering some 1.5 million households. By 2016, HUD's appropriation request for the HCV program had grown to $\$ 19.6$ billion, reflecting that its increase in coverage to 2.7 million households was far outstripping population growth.

2 Federal public housing and rental voucher programs are explicitly indexed to local prices by relying on local area median incomes (AMIs) to determine eligibility, and local fair market rents (FMRs)-a housing cost benchmark defined by HUD that typically corresponds to the 40th or 50th percentile rent for a standard-quality rental housing unit-to determine the level of benefits. See Appendix B in the Supporting Information for a detailed discussion of our data sources and calculations, including details on the administrative and empirical details on the HCV program, such as the relationship between payment standards and FMRs.

3 The paper that is perhaps closest in spirit to ours is Fisher, Pollakowski, and Zabel (2009) who propose an amenity-based housing affordability index for the Boston metro area. Our work differs in scope and focus in that we look at the interplay of amenities and housing subsidies at the national level.

4 See Eriksen and Ross (2015) and Metcalf (2018) for recent overviews of the housing affordability literature in a U.S. context. See Blomquist (2006), Gyourko, Kahn, and Tracy (1999), and Lambiri, Biagi, and Royuela (2007) for comprehensive surveys of the literature on amenity capitalization.

${ }^{5}$ HUD defines "low-income" as below $80 \%$ of the local AMI, "very low-income" as below 50\% of AMI, and "extremely low-income" as below $30 \%$ of AMI. The very low-income limit ( $50 \%$ of AMI) is the primary income limit used to determine eligibility for the HCV. See Appendix B. 2 in the Supporting Information for more details.
} 
in the Midwest to $\$ 4,860$ in the West. Second, we put these numbers into perspective by estimating amenity expenditures for very low-income households relying on Bieri, Kuminoff, and Pope's (2014) national data set on amenity expenditures. Under our preferred specification that is consistent with nonhomothetic preferences, we estimate that the average American very low-income household implicitly spends between $\$ 1,200$ (South) and $\$ 1,972$ (West) a year in order to enjoy local amenities. Our estimates indicate that a good third of HAPs correspond to the value of amenity consumption by HCV households. Third, we show that the spatial distribution of housing subsidies to very low-income households is highly skewed, favoring recipients who live in bigger coastal metropolitan areas where amenity-driven compensating differentials are large.

Our paper also highlights how the people-based affordability objectives of federal housing efforts potentially compete with locational and housing consumption efficiency-a tension that has increased dramatically since the housing crisis because the growth of median rents has, on average, outpaced personal income growth. Indeed, the underlying cause of this widely perceived "affordability crisis" is a historically unprecedented surge in U.S. rental demand over the last decade that has been fueled by a marked drop in homeowner rates and rapid demographic change. ${ }^{6}$ At the same time, however, the national narrative of uniform pressures on rental affordability reveals itself to be tale of two (types of) cities: For a good two-thirds of U.S. metro areas, rental housing has become more affordable, despite rising rents, as local income growth has lifted affordability pressures for median incomes (Edmiston, 2016). In the remaining third of mostly land-constrained coastal metros, rental affordability remains under intense demand-side pressure that shows no immediate signs of abating (Metcalf, 2018). In addition to such spatial inequality in rental affordability, secular increases in wage inequality have put additional policy emphasis on the lack of affordability among the large segment of vulnerable low-income renters. This includes predominantly urban households with incomes of less than $30 \%$ AMIs who account for over a quarter of the entire renting population. Moreover, these households tend to be overwhelmingly located in high-wage urban areas where demand for affordable units has consistently outpaced local supply. ${ }^{7}$

The increasing urgency of concerns over rental affordability has also led to renewed calls for reforming U.S. rental assistance programs (e.g., Olsen \& Zabel, 2015). Rather than explicitly arguing against the need for place-based policies on the basis of the conventional spatial equilibrium view, we examine options for improving the existing people-based housing policy of the HCV program. Indeed, our estimates permit the quantification of a novel scenario for housing policy reform, namely, one that adjusts current HAPs by the full amount of the average amenity expenditures of lowincome households in a given metro area. In a companion paper (Bieri \& Dawkins, 2016), we assess a variety of reforms that use amenity-adjusted housing subsidies and show that this could, ceteris paribus, boost national HCV program coverage by over $50 \%$.

In the broader context of efficiency-equity policy trade-offs, our work also raises the normative question of whether the current practice of means-tested federal housing subsidies that offset a large portion of differences in local amenity packages is horizontally equitable. If local amenity bundles are fully capitalized into housing values and wages, households living in low-amenity areas might be receiving lower quality housing bundles than those residing in high-amenity areas. Our results suggest that the level of indexation of HAPs under the current HCV program is comparatively high given the strong evidence for nonhomothetic household preferences and only weak complementarity between income and amenities (e.g., Black, Kolesnikova, \& Taylor, 2009; Handbury, 2016).

Furthermore, if the most productive parts of America are unaffordable simply because of excessive restrictions on local land use (Glaeser, 2017), housing voucher generosity indexed to rents might simply lead to more rent extraction by local governments (Diamond, 2017; Hilber \& Robert-Nicoud, 2013). Not only would such an indirect transfer of resources from federal to local governments deny the intended welfare improvements to low-income renters. But, because exclusionary restrictions on housing supply are likely to have a negative impact on intergenerational mobility

\footnotetext{
${ }^{6}$ With over 43 million Americans choosing to be tenants, the share of renters reached $37 \%$ in $2015-$ the highest share in the United States since the 1960 s (JCHS, 2015).

${ }^{7}$ At the national level in 2015 , almost $90 \%$ of renters with extremely low incomes were located in large urban counties where affordability is particularly low (Getsinger, Posey, MacDonald, \& Leopold, 2017). Most recently, the total shortage of affordable units for both urban and rural low-income households has be quantified to some 7.5 million units (NLIHC, 2017a, 2017b).
} 
and local inequality, increasing HCV program coverage, rather than voucher generosity, could enhance the effectiveness of federal housing policy goals.

The remainder of this paper proceeds as follows. We discuss housing affordability as a public policy objective in the next section, and Section 3 develops the theoretical links between affordability and quality of life, embedding housing affordability within a traditional setting of locational equilibrium. Section 4 then develops our empirical strategy, examining the evidence that links HCV subsidy payments to local amenity-based compensating differentials. We also discuss the impact of household heterogeneity and limited household mobility on our empirical results. Section 5 discusses options for policy reform on the basis of amenity-adjusted HAPs, whereas Section 6 offers some concluding thoughts.

\section{I PEOPLE, PLACES, AND PUBLIC POLICY}

The persistence of regional disparities in economic conditions presents a particular challenge to the traditionally people-based nature of federal housing policy. To the extent that it has been difficult to establish that spatial equilibrium obtains, it has become common practice to argue for place-based initiatives that address disparities in a geographically targeted manner (Partridge, Rickman, Olfert, \& Tan, 2015). In the case of housing, the presence of sizable externalities in the form of excessive restrictions on local land use or frictions in local labor market suggests that place-based housing investments may well be warranted to correct for a failure in urban housing markets (Kline \& Moretti, 2013, 2014; Schwartz, Gould Ellen, Voicu, \& Schill, 2005). At the same time, however, there is little consensus as to the overall effectiveness of spatially targeted policies as second best. Rather than arguing against the need for place-based policies on the basis of the conventional spatial equilibrium view, we echo the concern that major distortions in the rental housing market might have been indeed created by public policy. ${ }^{8}$ In this vein, Ortalo-Magné and Prat (2014) show that spatial equilibrium can be characterized by an undersupply of housing, particularly when federal housing policy introduces a persistent tension between the objectives of housing affordability for all and of homeownership for most.

As such, our focus in this paper is on examining the inherent tensions in the objectives of the most important peoplebased U.S. housing policy. By quantifying possible distortions that arise as a consequence of the current $\mathrm{HCV}$ program design, we hope to lay the foundations for a much needed discussions about options for policy reform that, in turn, might reduce the need for place-based housing interventions in the first instance. In addition to potentially competing objectives within the HCV program (affordability and access to high-amenity areas), this section also outlines an additional important tension between the people-based objectives of federal housing policy (housing inequality) and the (inherently place-based) objectives of locally autonomous land use regulation.

\subsection{HCV goals and the spatial variation of housing subsidies}

Since 1949, the central goal of U.S. housing policy "to provide adequate housing for urban and rural nonfarm families with incomes so low that they are not being decently housed in new or existing housing" has explicitly relied on "the reduction of the costs of housing without sacrifice of sound standards" (American Housing Act, 1949, p. 414). ${ }^{9}$ After several name changes and modifications to program design, most tenant-based subsidies funded by HUD now fall under the HCV program. ${ }^{10}$ A primary goal of the HCV program is to provide "opportunities for very low-income families to obtain rental housing outside areas of poverty or minority concentration" (HUD, 2001, our emphasis). This

\footnotetext{
8 The conventional rationale for a place-based program is the presence of public goods, amenities, agglomeration externalities and other spatial spillovers, labor market rigidities, or simply preexisting distortions from people-based policies. See Glaeser and Gottlieb (2008) for the standard spatial equilibrium view that argues against place-based policies and for recent evidence on the effectiveness of such policies.

${ }^{9}$ See Olsen and Zabel (2015) for a comprehensive overview of U.S. rental housing programs and the evidence of their effectiveness vis-à-vis specific policy goals.

${ }^{10}$ Over the years, the federal government has sought to implement its legislative mandate using three major approaches to manage housing affordability: (1) public housing that is constructed with federal subsidies and managed by local public housing authorities, (2) project-based subsidies designed to reduce the cost of constructing and managing low-income units, and (3) tenant-based subsidies that offset a portion of a low-income households' cost of renting a
} 
goal reflects two separate policy objectives that are often at odds with one another. On the one hand, as with all of HUD's programs, the HCV program is a means-tested program that aims to expand access to a decent home and suitable living environment for those unable to afford homes at prices prevailing in the local rental housing market. On the other hand, the HCV program is designed in part to encourage residential mobility to high-amenity areas that offer opportunities for upward economic mobility and social integration. Since housing prices tend to be higher in high-amenity areas, this second objective implies that HUD administrators must choose between spending an additional subsidy dollar to enable a qualified household to live in a more expensive location and awarding the same subsidy dollar to an additional low-income household not currently served by the program. Unlike other means-tested subsidy programs, the HCV is not an entitlement program, and local admissions priorities and waiting lists play an important role in determining who will receive scarce housing assistance dollars.

To assess the tensions between goals of the HCV program, we first need to quantify different elements of the housing cost burden for renters across regions from a variety of public sources for the year 2000, the reference year for our analysis. ${ }^{11}$ Table 1 describes the HCV program in terms of the spatial variation of its key policy dimensions, namely, program participation rates, the average size of HAPs, and housing cost burdens. Because the HCV program is not an entitlement, there is a significant amount of rationing regarding the vouchers; historically, roughly less than 1 in 10 of all eligible households end up participating in the program. More specifically, of all households who theoretically qualify for HCV assistance, only one-third actually apply to the program and only about a quarter of those households receive $\mathrm{HCV}$ assistance via locally administered lotteries. This implies a national average HCV participation rate of just under $10 \%$, with regional participation rates ranging from as little as 1 in 13 in the Midwest to almost one in eight in the Northeast. ${ }^{12}$ Table 1 highlights that HCV program participation varies significantly across space, with the highest program participation rates in coastal California and the New York to Boston corridor. Metro areas in the Midwest and in the South have the lowest participation rates. Among the 50 largest metro areas, HCV participation rates are highest in New York City (14.3\%) and lowest in Austin, TX (3.5\%).

In 2000, the HCV program covered some 1.25 million urban households who received a combined total of approximately $\$ 8.3$ billion in terms of housing subsidies. ${ }^{13}$ The average HCV recipient household earns just over a quarter of median household income of which it spends on average $\$ 2,323$ on rent, while receiving an average annual HAPsweighted by effective unit size and occupancy-of $\$ 4,262$. In other words, the average household subsidy in the HCV program is roughly twice as large as the average rent contribution by recipient households, the total tenant payment (TTP).

However, as Table 1 emphasizes, there is substantial regional variation in the size of these per-household subsidies, both in terms of their absolute magnitude and in terms of their size relative to the TTP. The annual housing subsidy to very low-income households in the Midwest is only $\$ 3,914$, whereas an equivalent household in the West would receives $25 \%$ more $(\$ 4,859)$. The spatial distributions of subsidies in the Midwest and in the South show the least dispersion, whereas subsidies in the West are spanning the largest range-a feature that is also mirrored in the spatial pattern of housing cost burdens among HCV recipients. ${ }^{14}$ In the Midwest, only approximately $\$ 3,700$ separate the metropolitan area where households receive the lowest average housing subsidies (Wausau, WI) and the

minimum-quality unit. Since the early 1970 s, the federal government has both expanded tenant-based housing assistance programs while at the same time demolishing a substantial portion of the public housing stock and eliminating most project-based subsidy programs administered by HUD.

${ }^{11}$ See Appendix B in the Supporting Information for a full description of our data sources and detailed definition of the methods and assumptions for creating key estimates. Housing cost burdens are calculated using data from HUD's Housing Affordability Data System (HADS). HAPs are population-weighted. HCV program participation rates are calculated by establishing population shares of qualifying households from census microdata using the basic income limits for very low-income households ( $50 \% \mathrm{AMI}$ ) and then expressing the number of $\mathrm{HCV}$ recipients as a fraction of the qualifying population using census tract-level data from HUD's Picture of Subsidized Households (PSH).

12 Because comprehensive microdata on HCV program applications are not available, we define participation rates as a share of HCV recipients relative to the theoretical base of all households that qualify calculated using HUD income limits and PUMS data.

13 Our analysis only considers HCV recipients who reside in metropolitan areas. Of the 1.47 million households who participated in the HCV program in the year 2000, 86\% (1.25 million) lived in an MSA.

14 In 2000, owner occupiers experienced on average the lowest housing burden (20.5\% of adjusted income is spent on housing), whereas renter households that obtained some form of housing assistance (HCV, public housing or project-based assistance) experience the highest burden (31.6\%). It is important to note, however, that affordability programs such as $\mathrm{HCV}$ s do not prevent renters from spending more than $30 \%$ of their income on rent, provided that housing 
TAB LE 1 HCV housing assistance payments for urban households, 2000

\begin{tabular}{|c|c|c|c|c|c|}
\hline & United States & $\begin{array}{l}\text { Northeast } \\
\text { (1) }\end{array}$ & $\begin{array}{l}\text { Midwest } \\
\text { (2) }\end{array}$ & $\begin{array}{l}\text { South } \\
\text { (3) }\end{array}$ & $\begin{array}{l}\text { West } \\
\text { (4) }\end{array}$ \\
\hline HCV households ('000s) ${ }^{a}$ & 1,248 & 320 & 235 & 376 & 316 \\
\hline Recipient annual income & $\$ 11,003$ & $\$ 11,476$ & $\$ 10,634$ & $\$ 9,759$ & $\$ 12,143$ \\
\hline Income as \% of AMI & $22.71 \%$ & $23.41 \%$ & $21.04 \%$ & $20.99 \%$ & $25.30 \%$ \\
\hline \multicolumn{6}{|l|}{ HCV participation ${ }^{b}$} \\
\hline Average participation rate & $9.77 \%$ & $12.10 \%$ & $7.69 \%$ & $8.68 \%$ & $10.23 \%$ \\
\hline \multirow[t]{2}{*}{ Min } & $0.45 \%$ & $2.83 \%$ & $1.71 \%$ & $0.70 \%$ & $0.45 \%$ \\
\hline & & Reading, PA & Holland, MI & Punta Gorda, FL & Prescott, AZ \\
\hline \multirow[t]{2}{*}{ Max } & $25.38 \%$ & $19.11 \%$ & $22.14 \%$ & $25.38 \%$ & $23.10 \%$ \\
\hline & & Burlington, VT & Grand Forks, ND & Warner Robins, GA & El Centro, CA \\
\hline \multicolumn{6}{|c|}{ Annual housing assistance payments ${ }^{c}$} \\
\hline Total HAP payments ( $\$ \mathrm{mn})$ & $\$ 8,321$ & $\$ 2,154$ & $\$ 1,553$ & $\$ 2,497$ & $\$ 2,117$ \\
\hline Average HAP payment & $\$ 4,262$ & $\$ 4,662$ & $\$ 3,914$ & $\$ 4,005$ & $\$ 4,859$ \\
\hline St. dev. & $\$ 1,090$ & $\$ 1,308$ & $\$ 681$ & $\$ 872$ & $\$ 1,350$ \\
\hline \multirow[t]{2}{*}{ Min } & $\$ 1,678$ & $\$ 2,594$ & $\$ 2,559$ & $\$ 1,678$ & $\$ 3,048$ \\
\hline & & York, PA & Wasau,WI & Dalton, GA & Lewistown, ID \\
\hline \multirow[t]{2}{*}{ Max } & $\$ 11,318$ & $\$ 7,556$ & $\$ 6,222$ & $\$ 7,518$ & $\$ 11,318$ \\
\hline & & Boston, MA & Chicago, IL & Washington, DC & San Jose, CA \\
\hline Housing cost burden $\theta^{h}$ & 0.254 & 0.250 & 0.251 & 0.249 & 0.270 \\
\hline TTP-HAP ratio $\psi$ & 0.629 & 0.640 & 0.675 & 0.594 & 0.639 \\
\hline \multicolumn{6}{|l|}{ Payment standard-FMR ratio ${ }^{d}$} \\
\hline Mean & 0.957 & 0.956 & 0.976 & 0.934 & 0.983 \\
\hline \multirow[t]{2}{*}{ Min } & 0.667 & 0.704 & 0.806 & 0.667 & 0.818 \\
\hline & & York, PA & Dayton, $\mathrm{OH}$ & Roanoke, VA & Bremerton, WA \\
\hline \multirow[t]{2}{*}{ Max } & 1.621 & 1.101 & 1.174 & 1.130 & 1.621 \\
\hline & & Burlington, VT & Terre Haute, IN & Hinesville, GA & Idaho Falls, ID \\
\hline$N$ (number of metro areas) & 358 & 45 & 89 & 148 & 76 \\
\hline
\end{tabular}

Note: HCV subsidies are defined as the average annual housing assistance payments (HAPs) that bridge the gap between the gross rent on a unit (FMR plus a 35\% utility allowance) and the maximum total tenant payments (TTPs) for a given household (capped at $30 \%$ of area median income for very low-income households), using census tract-level data from HUD's Picture of Subsidized Households (PSH).

aWe only consider HCV recipients who reside in metropolitan areas, corresponding to $86 \%$ of all HCV households in the year 2000.

${ }^{\mathrm{b}} \mathrm{HCV}$ program participation rates are calculated by establishing population shares of qualifying households from microdata using the basic income limits for very low-income households (50\% AMI) and then expressing the number of HCV recipients as a fraction of the qualifying population.

'MSA-specific average subsidies are calculated using population-weighted average federal spending per unit per month (plus admin fee) and the room-weighted average FMRs. The tenant payment-to-subsidy ratio is defined as $\psi \equiv \bar{r}^{\text {max }} / s^{*}=\bar{\theta}^{h} / \theta^{s}$, where $\bar{\theta}^{h} \equiv \bar{r}^{\max } / W^{*}$ is the housing share as fixed by policy and $\theta^{s} \equiv s^{*} / W^{*}$ is the subsidy share of income in the average location. ${ }^{\mathrm{d}}$ The average ratio between payment standards and the local FMRs provides a measure of the extent to which local conditions (including administrative decisions) factor into the HAP incidence.

Source: Authors' calculations from HUD Picture of Subsidized Households and Census PUMS data (see also Appendix B in the Supporting Information for a detailed description of data sources). 
metro area that pays the highest subsidies in nominal terms (Chicago, IL). In the West, however, HCV recipients in San Jose, the capital of Silicon Valley, receive almost four times the amount $(\$ 11,318)$ of recipients in Lewistown, ID $(\$ 3,048)$, a small agricultural and manufacturing metropolitan area that straddles the Idaho-Washington border. At the national level, the largest average annual housing subsidy (San Jose, CA) is almost seven times larger than the lowest average subsidy (Dalton, GA). By comparison, however, the cost of housing in terms of FMRs in the most expensive MSA (San Jose, CA) is just over four times higher than in the most affordable MSA (Idaho Falls, ID). ${ }^{15}$ Similarly, wage dispersion for low-income households is even lower than that of FMRs, with the $50 \%$ AMI threshold in the highest earning MSA (San Jose, CA) only exceeding that of the poorest MSA (Farmington, NM) by a factor of two and a half.

\subsection{Inequality and indexing}

In addition to the affordability-mobility tension within the HCV program discussed above, we identify an additional important tension between the people-based objectives of federal housing policy and the inherently place-based objectives of local land regulations-a tension that has been exacerbated in recent years by dramatic increases in wage inequality due to (skill-based) sorting across high-amenity metro areas, on the one hand, and more restrictive land use practices in those very places, on the other hand. ${ }^{16}$ This latter tension pits the social mobility objectives of federal housing policy squarely against the externalities of rent-seeking local government regulations. Because local land use regulation and housing supply restrictions are highly regressive in nature (Ikeda \& Washington, 2015), equitybased federal housing transfers might thus be desirable despite allocational efficiency concerns that are associated with the spatial equilibrium view that prescribes only minimal indexing of transfer payments to local prices. Indeed, as the top portion of Figure 1 illustrates, the size of HAPs tends to be highest in the most housing-constrained housing markets. Because land use restrictions reduce the elasticity of housing supply, there are potentially large efficiency losses from constraints on residential development (Gyourko \& Molloy, 2015; Hsieh \& Moretti, 2017), even if housing supply elasticities do not appear to affect the housing cycle (Davidoff, 2013), and hence, the cyclical components of changes in rental affordability. ${ }^{17}$ However, while it might be desirable for federal housing policy to lean against local supply-side drivers of housing cost pressures, this might entail at least two additional unintended consequences. First, in the absence of a migration response, limits on land use that impact housing supply elasticity increase the market power of local governments (Diamond, 2017), which, in turn, would simply lead to more rent extraction by local governments. Second, unless voucher indexing took place at the neighborhood level instead of at the metro level, housing voucher generosity benefits landlords through increased rents, with minimal impact on neighborhood and unit quality (Collinson \& Ganong, 2018).

These immediate efficiency-equity considerations notwithstanding, there is an additional channel through which the HCV program might convey external benefits to low-income renters in an intergenerational setting. Specifically, the broader social justifications for government intervention in the low-income housing market suggests, as we discussed above, that residential mobility to high-amenity areas generates opportunities for the upward economic mobility and social integration of low-income households. Thus, there might be a link between intergenerational mobility and participation in the HCV program that counteracts the negative effects of local income inequality due to skill

costs do not exceed $40 \%$ of income when a new lease is signed. For example, under HCV rules, a two-person household is not prevented from renting a threebedroom apartment, thus limiting the usefulness of the rent burden as a measure of housing policy effectiveness.

15 Despite virtually identical rent and income levels, average annual housing subsidy payments in Idaho Falls, ID (\$3,627) are more than double those in Dalton, GA (\$1,678). This is largely because the average payment standard in Idaho Falls is almost $50 \%$ higher than that in Dalton. As we discuss in Appendix B.4 in the Supporting Information in more detail, administrative discretion on part of the local housing authorities introduces an element of local variation into the relationship between payment standards and FMRs. We account for this source of variation in the analysis that follows.

16 See Diamond (2016) and Moretti (2013) for a discussion of skill-based wage inequality across U.S. metros and Glaeser, Gyourko, and Saks (2005), Gyourko and Molloy (2015), Hilber, Lyytikäinen, and Vermeulen (2011), Ihlanfeldt (2007), Quigley and Raphael (2004), and Saiz (2010) for a well-established literature that links land use regulation to constraints in the supply and affordability of housing.

17 Decomposing the welfare effects of land use regulations into own effect, external effect, and supply effect, Turner, Haughwout, and van der Klaauw (2014) conclude that small reductions in land use regulation in the United States could lead to large welfare gains. 


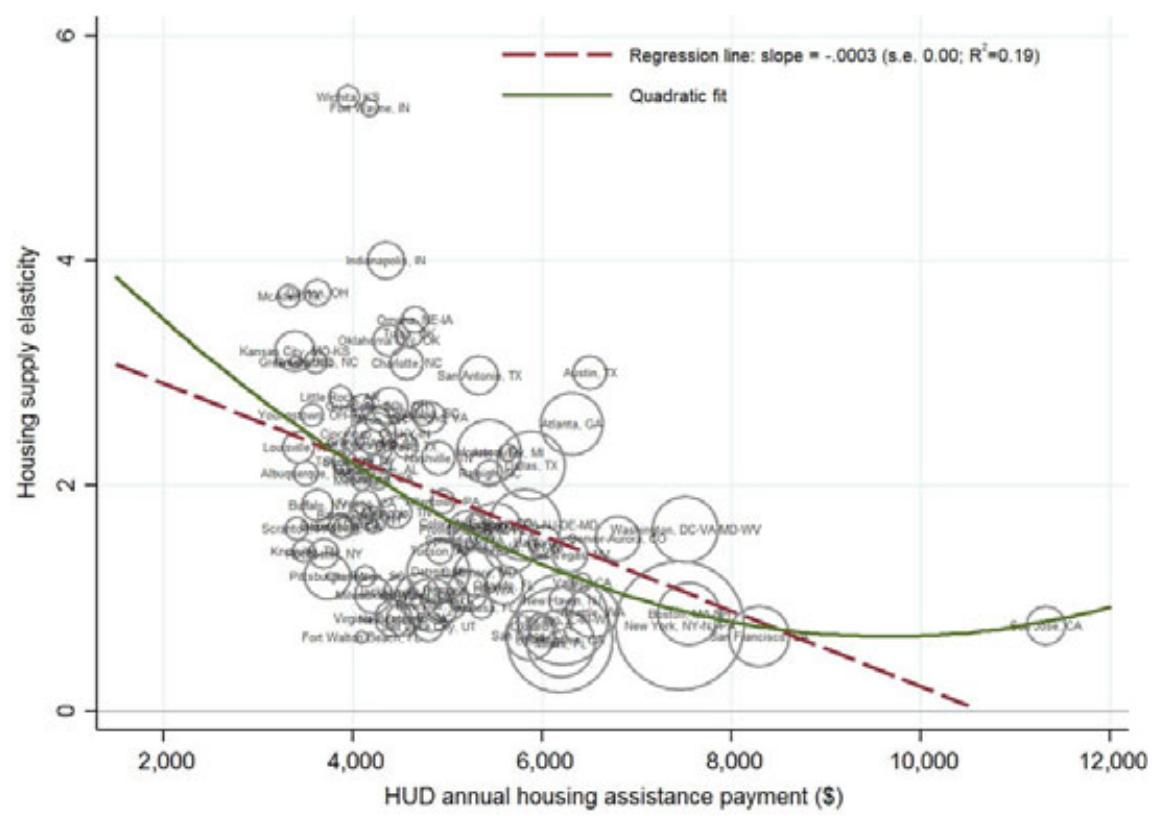

(a) Housing assistance payments (HAPs) and local housing supply elasticity

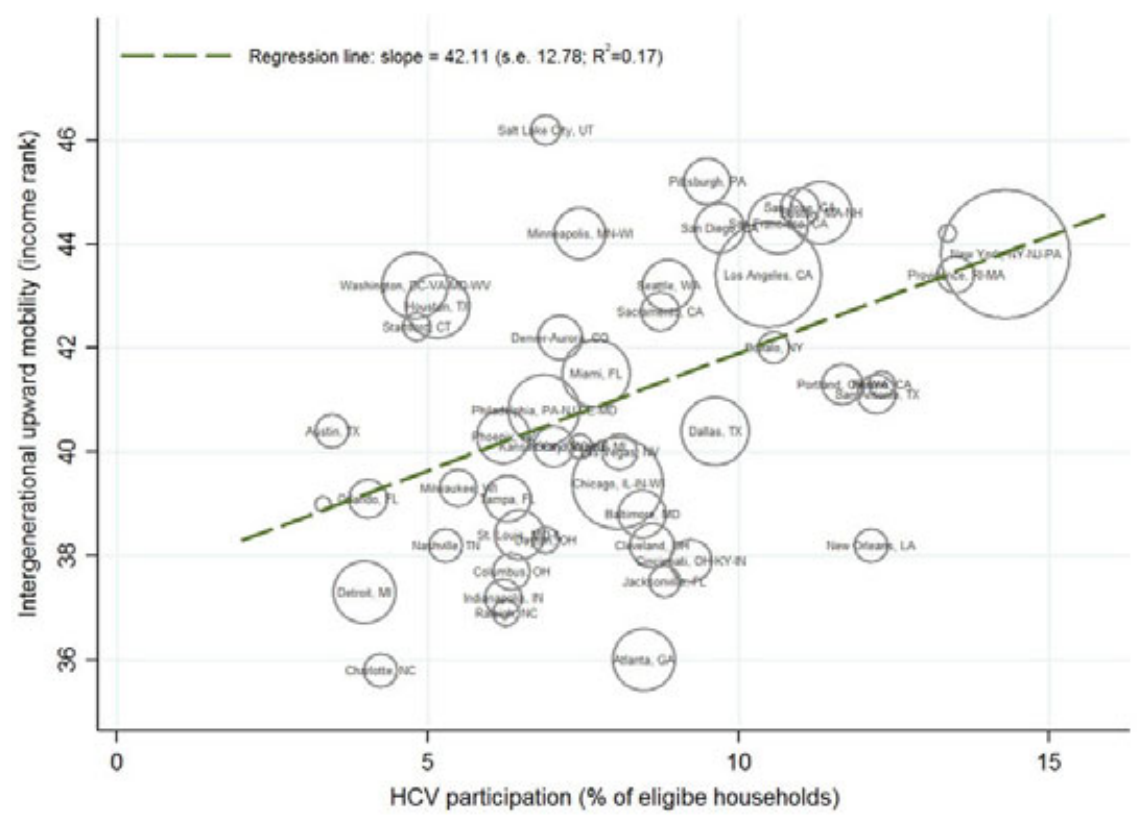

(b) HCV participation and intergenerational mobility

FIGURE 1 The inherent tension among HCV program objectives (affordability vs. upward mobility) [Color figure can be viewed at wileyonlinelibrary.com]

Notes: Panel (a) illustrates the link between the size of housing assistance payments and local housing supply elasticity. Panel (b) shows the relationship between spatial dispersion in intergenerational mobility and participation in the HCV program. Intergenerational upward mobility measures are from Chetty et al. (2014) and indicate the predicted percentile rank of the children's income at parent income rank equal 25. Housing supply elasticities are from Saiz (2010). 
sorting and increases in endogenous urban amenities. At least at a cursory glance, the bottom part of Figure 1 suggests that increasing participation in the HCV program among eligible low-income households might be associated with higher levels of intergenerational mobility. Furthermore, as intergenerational mobility and local inequality are negatively impacted by exclusionary restrictions on housing supply (Chetty, Hendren, Kline, \& Saez, 2014; Levine, 2006), the HCV program sits at the very nexus between regulation, the stagnation in U.S. labor mobility, and widening income inequality. ${ }^{18}$

Returning to our original point of departure, the preceding discussion has highlighted important counterarguments that modify the efficiency-based view whereby the optimal level of spatial indexing in the presence of amenity-induced compensation differentials must be such that optimal HAPs simply equalize the marginal utility of income between households across locations. When people are sufficiently immobile such that (long-run) well-being is not equalized across space, indexing transfer payments to local prices might help to improve both efficiency and equity. In this scenario, it could be desirable that some indexing to local prices renders high-cost location more attractive, ultimately inducing a reallocation of households and production among locations. ${ }^{19}$

Because HAPs to HCV recipients are fully indexed to local prices as they are calculated based on nominal income and rents, the federal government engages in an indirect form of location-based redistribution. While such an equalization of the real value of federal housing transfers across space is only (horizontally) equitable under the considerations outlined above, it is important to quantify how the spatial cost-of-living adjustments in the HCV program relates to local differences in the (implicit) amenity expenditures by low-income households. ${ }^{20}$ With limited mobility, ceteris paribus, indexing to local cost of living is only optimal under the assumption that amenities and income are complements. ${ }^{21}$ Thus, the complete indexing of HCV HAPs is only optimal if trading off more choice over location fully outweighs distortions in locational efficiency. The following section formalizes this argument in order to quantify the magnitude of amenity-based compensating differentials that are contained in HAPs.

\section{3 | AMENITIES AND HOUSING AFFORDABILITY}

This section models tenant-based subsidies that are tied to a fixed housing cost burden and a local rent index in a spatial equilibrium framework, where different amenity endowments-in combination with the locational sorting behavior of heterogeneous households and firms-support different combinations of interurban rent-wage differentials (Bayer, Keohane, \& Timmins, 2009; Blomquist, Berger, \& Hoehn, 1988; Roback, 1988). Our point of departure is a dual-market sorting equilibrium wherein households choose from a finite number of spatially bounded localities $j=1,2, \ldots, J$ in order to maximize utility (see Appendix $\mathrm{C}$ in the Supporting Information for a full specification of the model). Following the standard approach in the sorting literature, we use the properties of equilibrium to deduce a vector of amenity prices that implies identical levels of well-being across locations such that households cannot improve their utility by

\footnotetext{
18 See Furman (2015) and Furman and Orszag (2015) for a more detailed discussion of the link between land use regulation and inequality.

19 The indexing of government transfers to temporal changes in the cost of living is a widely accepted practice. Theoretical questions regarding this practice largely arise in the context of optimal implementation, such as, for example, whether government programs should be indexed against a group-specific cost-ofliving index or the general consumer price index (Jorgenson \& Slesnick, 1999). However, the arguments for a temporal indexation of transfers do not translate analogously to indexing for spatial variation in the cost of living. When locations differ in amenities, cost-of-living comparisons become difficult, and spatial cost-of-living adjustments can become problematic because of amenity-induced compensation differentials (Black, 2011).

20 Glaeser (1998) derives the conditions under which it is appropriate for federal transfer payments to be adjusted for local variations in the cost of living within the setting of a standard spatial equilibrium model. He concludes that current levels of indexing of major U.S. transfer programs are too high and that the optimal transfer depends on mobility and preferences for amenities.

21 If amenities and income are complements, the marginal utility of income $(\partial U / \partial w)$ in high-cost locations $r_{h}$ is larger than the marginal utility of income in less expensive locations $r_{l}$, i.e., $\left.\frac{\partial U}{\partial w}\right|_{r_{h}}>\left.\frac{\partial U}{\partial w}\right|_{r_{l}}$, thus warranting some indexing of transfer payments. If amenities and income are substitutes, households in high-cost areas will have lower real incomes but they enjoy higher amenities that have offsetting effects on the marginal utility of income such that $\left.\left.\frac{\partial U}{\partial W}\right|_{r_{h}} \approx \frac{\partial U}{\partial w}\right|_{r_{l}}$.
} 
relocating (Kuminoff, Smith, \& Timmins, 2013). ${ }^{22}$ As we derive in Appendix C in the Supporting Information, we can express a measure of (implicit) local amenity expenditure, $\tilde{z}_{j}$, in terms of relative housing costs, $\tilde{r}_{j}$, and wage levels, $\tilde{w}_{j}$ i.e.,

$$
\tilde{z}_{j}=\theta^{h} \tilde{r}_{j}-\tilde{w}_{j}
$$

where $\theta^{h} \equiv \frac{r^{*}}{w^{*}}$ is the income share of housing. Thus, the first term of Equation (1) indicates in percentage terms how high the cost-of-living is in city $j$ relative to the national average, whereas the second term represents how high local nominal income is. For expositional tractability in what follows, we temporarily impose the restriction that households are homogenous and freely mobile. However, we also show in Appendix C in the Supporting Information that our more general model nests Roback's (1982) standard model of compensating differentials if we impose these restrictions. More importantly, Roback (1988) demonstrates that-for as long as we can assume that amenity expenditures increase with income-the introduction of heterogeneous households (workers differentiated by skill level) leaves the key predictions of the model with homogeneous agents about the nature of amenity-driven wage and rent compensating differentials intact. Indeed, as workers' types tend to compete among themselves and not with other groups, regional wage differentials are compensating for amenities within skill groups. In this setting, as we illustrate in more detail in Section 4.2 below, the wages of the skilled (high income) will fall relatively more than those of the unskilled (low income) as they move to high amenity ares. ${ }^{23}$ Overall then, the presence of segmented labor and housing markets preserves the equilibrium predictions of the standard sorting model with a single household type which permits us to maintain this simplifying assumption in what follows.

To illustrate the issues with the " $30 \%$ rule" in the current HCV approach, consider the top portion of Figure 2 that shows the comparative statics of the Rosen-Roback framework for housing subsidies among two locations, $A$ and $B$, with different amenity endowments. If affordability goals are operationalized via a fixed income share $\bar{\theta}^{h}$, the locus of fixed rent-to-income corresponds to the dashed ray out from the origin. Relative to the national average wage-rent equilibrium at $\left[w^{*}, r^{*}\right]$, location $A$ has above average household amenities $\left(z^{*}<z_{A}\right.$; lower wages, higher rents) and location $B$ has below average amenities $\left(z^{*}>z_{B}\right.$; higher wages, lower rents), assuming that these amenities produce no productivity effects in both locations. Furthermore, suppose that the rent-to-income ratio in location $B$ exactly coincides with the national housing affordability threshold $\left(\bar{\theta}^{h}=\frac{r_{B}}{w_{B}}\right)$. Relative to location $B$, both the average national rent-wage ratio and that prevailing in location $A$ are higher as both locations exhibit superior amenity endowments $\left(\bar{\theta}^{h}<\frac{r^{*}}{w^{*}}<\frac{r_{A}}{w_{A}}\right)$. The extent of the HAP in location $A, s_{A}$, is then equivalent to the difference between the locationspecific equilibrium rent, $r_{A}$, and the maximum TTPs as defined by housing policy, $r_{A}^{\max }$, such that $r_{A}=s_{A}+r_{A}^{\max }$. Because wages are decreasing in amenities and rents are increasing in amenities under this setup, the size of the equilibrium housing subsidy necessarily increases with quality-of-life compensating differentials.

In practice, HAPs in a given metro area are determined by the level of local FMRs relative to prevailing AMIs. ${ }^{24}$ Differences in FMRs thus also capture differential amenity bundles across areas. Under the existing HCV program rules, this implies that the policy ceiling on housing consumption can vary spatially for identical HCV households in identical units. More formally, an HCV participant in locality $j$ in a unit with an applicable FMR, $r_{j}$, pays a constant fraction $\bar{\theta}^{h} \equiv \frac{r_{j}^{\max }}{w_{j}}=0.3$ of (adjusted) income $w_{j}$ in rent, such that the housing subsidy in location $j, s_{j}$, is then defined as $s_{j}=r_{j}-\bar{\theta}^{h} w_{j}$. The participant household's consumption of other goods would be $\left(w_{j}-\bar{\theta}^{h} w_{j}\right) / p_{j}^{x}$. If the participant occupied a unit renting for less than the applicable FMR, she would pay a fraction $\bar{\theta}^{h} w_{j} / r_{j}$ of the rent. ${ }^{25}$

\footnotetext{
22 Even if spatial equilibrium might not fully obtain, particularly in the labor market, the likely magnitude of the bias in amenity valuations appears to be "relatively minor, both quantitatively and qualitatively" (Greenwood, Hunt, Rickman, \& Treyz, 1991, p. 1389).

23 See also Beeson (1991) and Black et al. (2009) on these points.

${ }^{24}$ As we discuss in more detail in Appendix B in the Supporting Information, TTPs are technically calculated against a local "payment standard" that is a function of the prevailing FMR benchmark. In establishing the payment standard, each public housing authority (PHA) has a certain amount of administrative discretion within several ranges of FMRs to adjust maximum HAPs in line with specific conditions in the local rental market.

25 See Olsen (2003) for more details on the policy impact on consumption patterns of HCV recipients.
} 


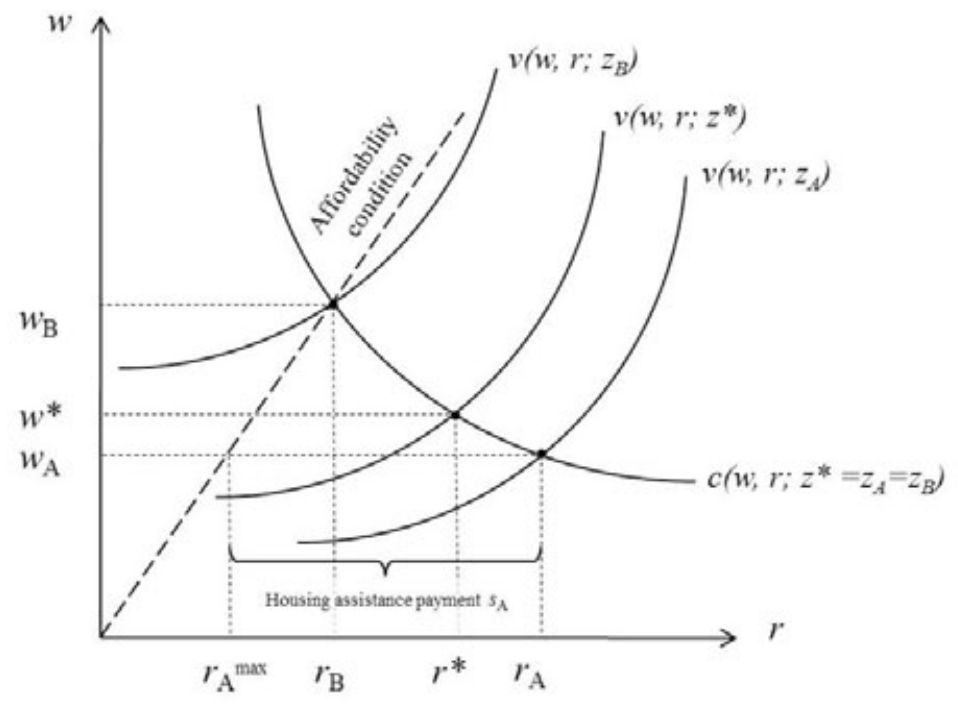

(a) Affordability condition under Rosen-Roback restrictions

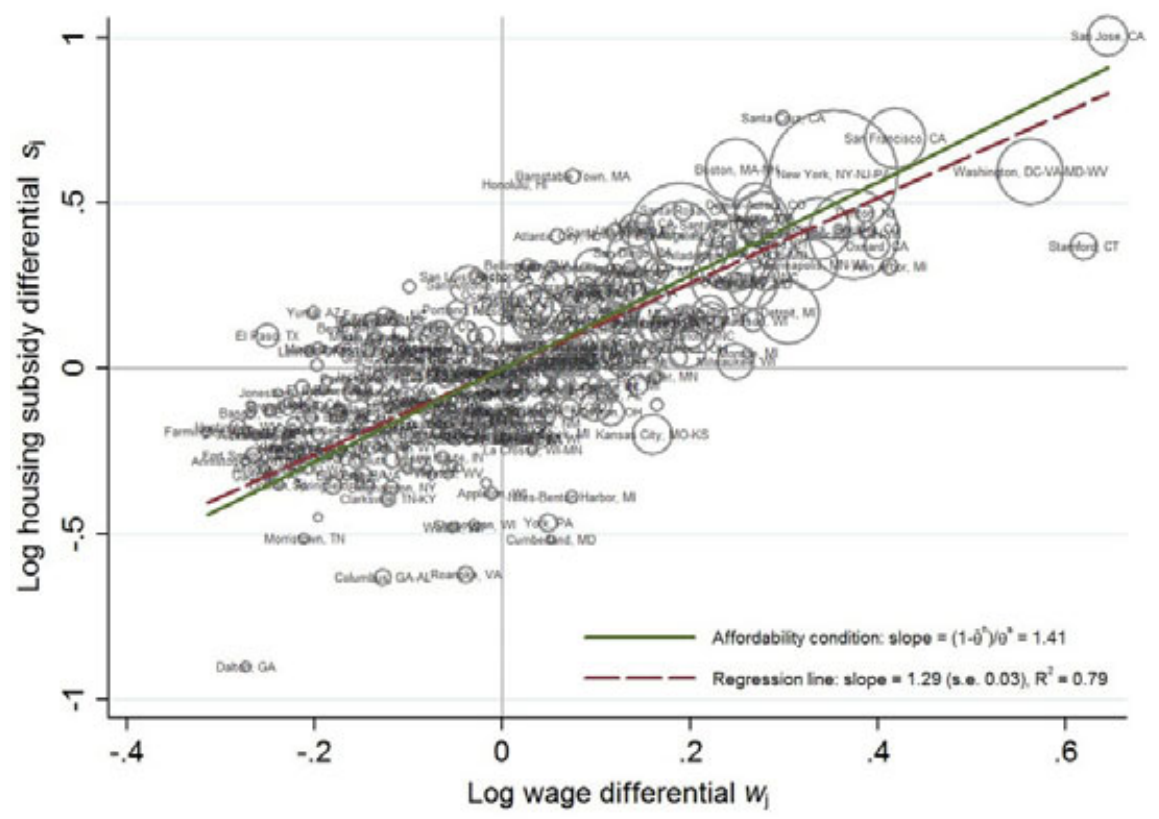

(b) Calibrated affordability condition

FIGURE 2 Housing subsidies based on a fixed rent-to-income ratio [Color figure can be viewed at wileyonlinelibrary.com]

Notes: Panel (a) illustrates the impact of a national rent-to-income ratio on housing subsidies. The extent of the housing assistance payment in high-amenity location $A, s_{A}$, is the difference between the location-specific equilibrium rent $r_{A}$ and the respective total tenant payment, $r_{A}^{\max }$, that corresponds to the affordability ratio as defined by housing policy. Panel (b) graphs the relationship between log housing subsidy differentials and quality-adjusted wage differentials. The solid line represents the calibrated affordability condition in Equation (3) for metropolitan areas with average amenity expenditures. 
In order to express how high the housing subsidy in city $j$ is relative to the national average as a function of relative rents and relative wages, we log-linearize the expression for housing subsidy $s_{j}=r_{j}-\bar{\theta}^{h} w_{j}$, letting $\tilde{s}_{j} \equiv d s_{j} / s^{*}, \tilde{r}_{j} \equiv d r_{j} / r^{*}$, and $\tilde{w}_{j} \equiv d w_{j} / w^{*}$, such that

$$
\tilde{s}_{j}=\phi \tilde{r}_{j}-\psi \tilde{w}_{j}
$$

where $\phi \equiv \theta^{h} / \theta^{s}, \psi \equiv \bar{\theta}^{h} / \theta^{s}$, and $\theta^{s} \equiv \frac{s^{*}}{w^{*}}$ is the income share of the subsidy in the average location (analogous to the housing share $\left.\theta^{h} \equiv \frac{r^{*}}{w^{*}}\right)$. Consistent with the intuition developed in Figure 2, Equation (2) thus reflects that, in percentage terms, relative housing subsidies $\tilde{s}_{j}$ are higher, the more local rent levels exceed local incomes, scaled by how much the equilibrium rent-to-income ratio in the average location $\theta^{h}$ deviates from the national affordability ratio $\bar{\theta}^{h}$. Because house prices (rents) are the major driver of the local cost-of-living, cities with low real incomes relative to the national average receive the highest subsidies, irrespective of whether real wages are low because of low nominal incomes or because of high cost of living due to amenities. Substituting Equation (1) into Equation (2), we are able to obtain an equilibrium expression for the relative housing subsidy $\tilde{s}$ in terms of relative amenity expenditures $\tilde{z}$ and relative wages $\tilde{w}$, i.e.,

$$
\tilde{s}_{j}=\frac{1}{\theta^{s}} \tilde{z}_{j}+\frac{1-\bar{\theta}^{h}}{\theta^{s}} \tilde{w}_{j}
$$

Equation (3) implies that the housing subsidy in location $j$ is a share-weighted average of relative amenity expenditures and the local wage differential, using the size of the subsidy relative to income and relative to the tenant payment as weights. Given that the possible range of values for $\theta^{s}$ and $\bar{\theta}^{h}$ imply strictly positive weights, an initial calibration of (3) for our sample suggests that housing subsidies unambiguously increase with relative amenity expenditures.

The empirical relationship between log housing subsidy differentials $\tilde{s}_{j}$ and quality-adjusted wage differentials $\tilde{w}_{j}$ implied in (3) is plotted in panel (b) of Figure 2, where the solid line represents the calibrated "affordability condition" for metro areas with average amenity expenditures $\left(\tilde{z}_{j}=0\right)$. Along this locus, housing subsidies rise with wage levels such that the subsidy share of income $\theta^{s}$ remains consistent with a constant national affordability ratio. When relative housing subsidies in a given location are above (below) this line, households incur implicit amenity expenditures that are higher (lower) than average in proportion to the vertical distance from the line. In other words, in desirable locations such as San Francisco (above the solid line), HCV subsidies cover a larger than average share of amenity expenditures, whereas the opposite is true in less desirable locations such as Detroit (below the solid line). The dashed line in panel (b) is estimated via a (population-weighted) regression of log housing subsidy differentials on log wage differentials. The $p$ value of a test that this regression slope equals the slope of the calibrated affordability condition, $\left(1-\bar{\theta}^{h}\right) / \theta^{s}$, suggests that the two parameters are very close. This first parameterization of Equation (3) provides the motivation for a series of more systematic empirical tests of the relationship between housing subsidies and amenity expenditures.

\section{4 | EMPIRICAL EVALUATION OF HOUSING SUBSIDIES}

Our theoretical model in the previous section suggests that a portion of inter-metropolitan differentials in HCV subsidies reflects intermetropolitan amenity differentials. To test this conjecture and to provide precise estimates of the extent of amenity-based HCV compensation, we proceeds as follows. We begin by estimating implicit amenity expenditures for low-income households, paying particular attention to the impact of household heterogeneity. We then test the empirical content of our model by evaluating the extent to which the spatial variation in HAPs is driven by the size of implicit amenity expenditures by HCV recipient households. After performing a series of robustness checks, we explore the consequences of our findings for housing policy reform. 
TABLE 2 Estimated amenity expenditure shares

\begin{tabular}{|c|c|c|c|}
\hline \multirow[t]{4}{*}{ Dependent variable } & \multicolumn{3}{|c|}{ Average amenity expenditure share $\bar{\sigma}_{i}^{z}$} \\
\hline & \multirow{3}{*}{$\begin{array}{l}\text { OLS } \\
\text { (1) }\end{array}$} & \multicolumn{2}{|l|}{$\underline{\text { GLM }}$} \\
\hline & & coefficients & $\partial x / \partial y$ \\
\hline & & (2) & (3) \\
\hline \multicolumn{4}{|l|}{ Independent variables } \\
\hline \multirow[t]{2}{*}{ Average household income } & $0.081^{* *}$ & $0.089^{* *}$ & $0.075^{* *}$ \\
\hline & $(0.029)$ & $(0.003)$ & $(0.027)$ \\
\hline \multirow[t]{2}{*}{ Return to college } & $-0.096^{* *}$ & $-1.143^{* *}$ & $-0.096^{* *}$ \\
\hline & $(0.036)$ & $(0.417)$ & $(0.035)$ \\
\hline \multirow[t]{2}{*}{ Unemployment (\%) } & $0.623^{* * *}$ & $7.031^{* * *}$ & $0.592^{* * *}$ \\
\hline & (0.139) & $(1.501)$ & $(0.127)$ \\
\hline \multirow{2}{*}{ Minority population (\%) } & $0.123^{* * *}$ & $1.480^{* * *}$ & $0.125^{* * *}$ \\
\hline & $(0.024)$ & $(0.285)$ & $(0.024)$ \\
\hline \multirow[t]{2}{*}{ Retirees (\% over 65) } & $0.279^{*}$ & $3.352^{* *}$ & $0.282^{* *}$ \\
\hline & $(0.111)$ & $(1.221)$ & $(0.102)$ \\
\hline \multirow[t]{2}{*}{ Owner occupiers (\%) } & $-0.245^{* * *}$ & $-2.862^{* * *}$ & $-0.241^{* * *}$ \\
\hline & $(0.052)$ & $(0.599)$ & $(0.050)$ \\
\hline \multirow[t]{2}{*}{ Single family houses (\%) } & $-0.102^{* *}$ & $-1.160^{* *}$ & $-0.098^{* *}$ \\
\hline & $(0.035)$ & $(0.403)$ & $(0.034)$ \\
\hline \multirow[t]{2}{*}{ Married with children (\%) } & 0.083 & 1.100 & $0.093^{\dagger}$ \\
\hline & $(0.069)$ & $(0.765)$ & $(0.063)$ \\
\hline$R^{2}$ or log pseudolikelihood & 0.309 & -80.695 & $\cdots$ \\
\hline$N$ (number of metro areas) & 358 & & \\
\hline
\end{tabular}

Note: Huber-White robust standard errors are in parentheses. Regressions include intercept (not reported). The standard errors of the marginal effects for the GLM model are calculated using the delta method that assumes that values of the covariates used to calculate the response are given. MSA-level returns to college are from Black et al. (2009). Significance levels: $p<0.10,{ }^{*} p<0.05,{ }^{* *} p<0.01,{ }^{* * *} p<.001$.

\subsection{Estimating low-income amenity expenditures}

In order to quantify the extent to which interurban amenity differentials interact with HCV housing subsidies, we use a new national data set by Bieri et al. (2014, BKP) on local amenity expenditures by average households. The BKP data on indirect amenity expenditures are estimated using a methodology that is consistent with both the principles of national accounting and the fundamentals of spatial sorting behavior. The data set includes a wide variety of geographic and climate characteristics, environmental externalities, local public goods, infrastructure characteristics, and cultural and urban amenities (see Section 4.2 and Table 4 below for more descriptive detail of the BKP data). Relative to the quality-of-life literature, the BKP estimates incorporate a number of relevant methodological improvements, including a comprehensive national database on over 70 spatially delineated amenities, migration data to account for moving costs, spatial variation in the user cost of housing (and hence, taxation), and extensive controls to address endogeneity effects due to spatial Roy sorting. ${ }^{26}$ We estimate implicit expenditures for low-income households from the BKP data under two different sets of assumptions. First, we suppose that low-income households have homothetic preferences, which implies constant amenity expenditure shares across all income levels. Second, we derive amenity expenditure estimates for HCV households assuming that households' tastes vary with income. Under this more realistic setting

${ }^{26}$ See Appendix C.2 in the Supporting Information for more details on the Bieri et al. (2014) data and its empirical methodology. 
TAB LE 3 Amenity expenditure shares for very low-income households

\begin{tabular}{|lcc|} 
& $\bar{\sigma}^{z}$ constant & $\sigma_{\gamma}^{z}<\overline{\boldsymbol{\sigma}}^{z}$ \\
& $(1)$ & $(2)$ \\
\hline (Unweighted) mean & $9.23 \%$ & $6.72 \%$ \\
\hline Standard deviation & $4.19 \%$ & $1.96 \%$ \\
\hline Lowest expenditure share & $0.61 \%$ & $0.61 \%$ \\
\hline 10th percentile & $4.80 \%$ & $4.61 \%$ \\
\hline 25th percentile & $6.21 \%$ & $5.47 \%$ \\
\hline Median expenditure share & $8.42 \%$ & $6.65 \%$ \\
\hline 75th percentile & $11.53 \%$ & $7.88 \%$ \\
\hline 90th percentile & $14.88 \%$ & $9.41 \%$ \\
\hline Highest expenditure share & $24.82 \%$ & $11.98 \%$ \\
\hline
\end{tabular}

Note: Unit of observation is the MSA. Very low-income households are households with annual incomes below $50 \%$ of AMI.

TABLE 4 Amenity expenditures by urban household type

\section{United States}

Northeast

(1)

Average households (BKP data)

Average household income

Amenity expenditures

Income share $\bar{\sigma}^{z}$

Amenity expenditures ( $\$ \mathrm{mn}$, all hhs)

Low-income households ${ }^{\mathrm{a}}$

Average amenity expenditures

Income share $\sigma_{\gamma}^{z}$

Amenity expenditures ( $\$ \mathrm{mn}$, low-income hhs)

\section{Average amenity expenditures}

Income share $\sigma_{\gamma}^{z}$

Amenity expenditures ( $\$ \mathrm{mn}$, low-income hhs)

Total amenity expenditure as $\%$ of HAP

$\$ 59,681$
$\$ 5,736$
$9.5 \%$

$\$ 64,102$

Midwest

South

West

(2)

(3)

(4)

Note: Estimates for amenity expenditures are for urban households only, based on data from Bieri et al. (2014). All regional averages and shares are calculated from metro area data and are population-weighted (MSA population and HCV population, respectively). See text and Section 4.1 for details on estimation of amenity expenditures by very low-income households. ${ }^{a}$ Although shares for low-income households under the assumption of homothetic preferences are identical to average shares at the metro level by definition, weighted averages for $\sigma_{\gamma}^{z}$ diverge due to differences in population-weights (HCV participation varies across MSAs).

of nonhomothetic preferences, household amenity expenditure shares for low-income households will be lower than those of the average household, provided that amenities are at least normal goods.

For the first set of estimates, we simply scale the BKP amenity expenditures for average households by the local incomes of low-income households, taking advantage of the fact that homotheticity implies unitary income elasticity. Low-income amenity expenditure shares, $\sigma_{\gamma}^{z}$, are then constructed by accounting for distributional characteristics of regional incomes. For the second set of estimates, we exploit an insight from Beeson (1991) who establishes a link between returns to education and location-specific amenities within the framework of spatial sorting. Specifically, we benefit from a recent extension of this work by Black et al. (2009) who demonstrate that the empirical regularity of 


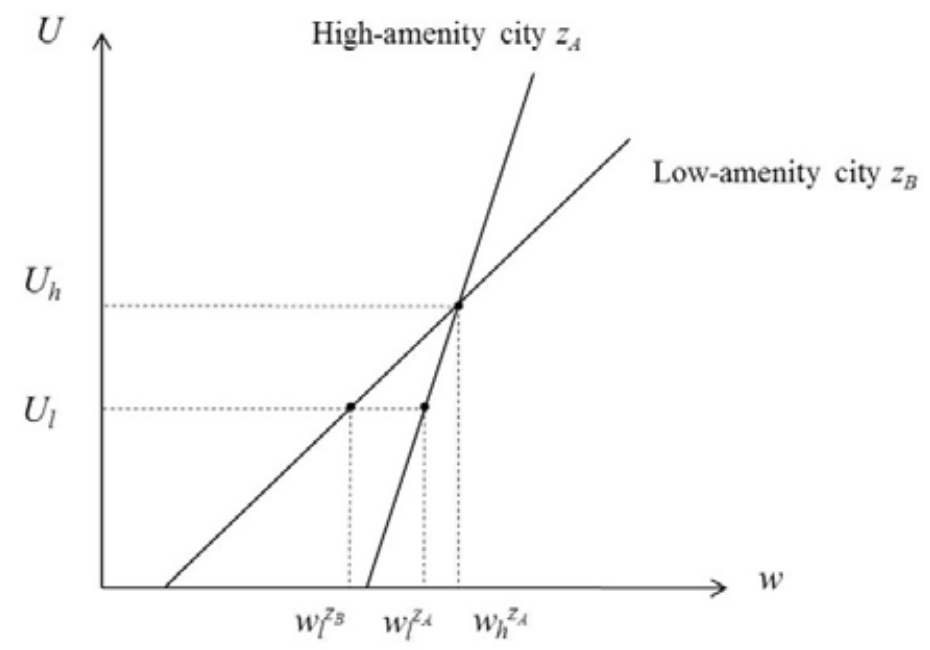

(a) Wage-education gradients with nonhomothetic preferences

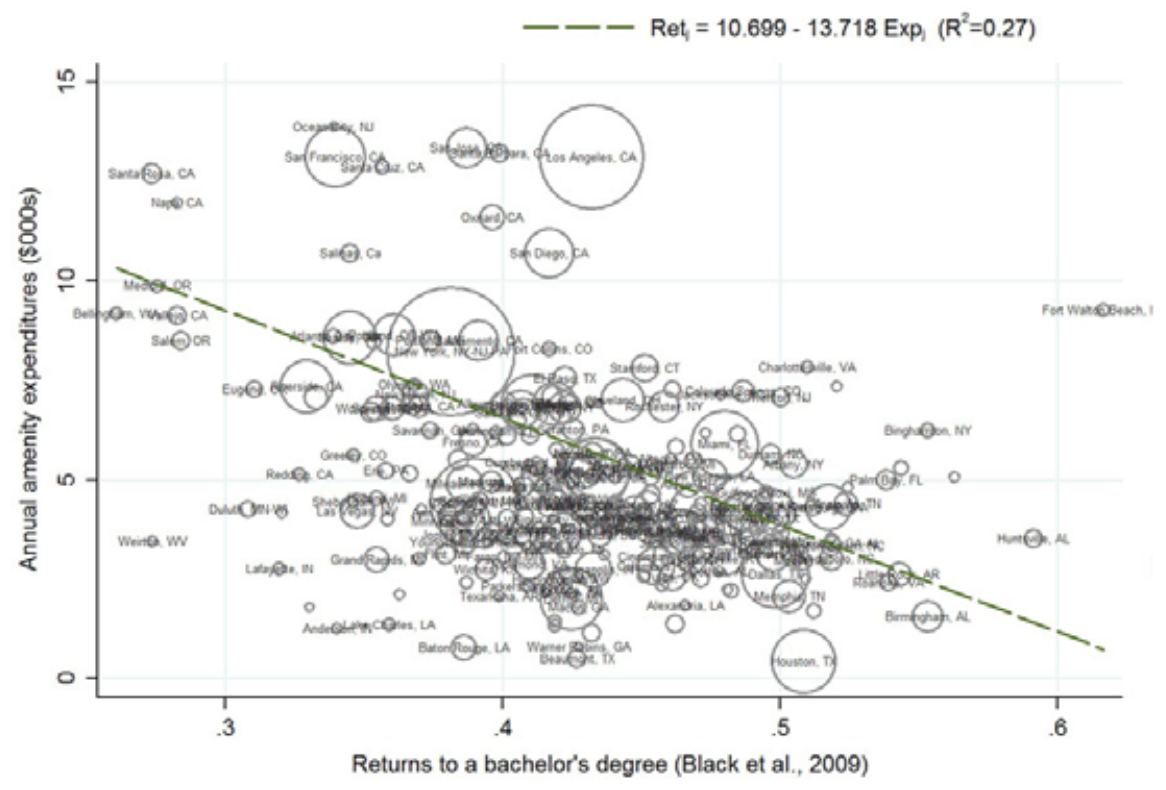

(b) Returns to education and amenity expenditures

FIGURE 3 Wages, nonhomothetic preferences, and amenities [Color figure can be viewed at wileyonlinelibrary.com] Sources: Returns to education are Black et al.'s (2009) mean estimated returns to a bachelor's degree. Amenity expenditures are from Bieri et al. (2014).

relatively low returns to education in expensive high-amenity locations is theoretically consistent with nonhomothetic preferences. We then use this result to derive amenity expenditure shares for low-income households using the BKP data. Figure 3 helps to build the intuition of how we can use the inverse relationship between local returns to education and amenities when preferences are nonhomothetic. To begin, consider two types of households who are identical except in their level of skill-based earning potential and who choose to locate either in high-amenity city $A$ or in lowamenity city $B\left(z_{A}>z_{B}\right)$. In line with Black et al. (2009), we assume that there is a utility cost to acquiring education such that household utility maximization entails choosing the optimal level of education, the preferred location, and the best consumption bundle given the education level and location. 
Panel (a) illustrates the wage-education gradients for both cities where low-education households have utility level $U_{l}$ and high-education households have utility level $U_{h}$. For expositional simplicity, we assume that the high-education household earns $w_{h}$ that is the same in $A$ as it is in $B$, because, for example, there is a national labor market for the highly educated. By contrast, the wages for low-education households are higher in the high-amenity city than they are in the low-amenity city $\left(w_{1}^{z_{A}}>w_{1}^{z_{B}}\right)$, because if preferences are nonhomothetic, they are willing to spend less on amenities than do their high-education counterparts. Low-education households are indifferent between living in the high- or low-amenity city only if wages are higher in the high-amenity city. Therefore, the wage-education gradient must be steeper in the high-amenity city that, in turn, implies that the marginal utility of income is lower in low-amenity cities than in high-amenity cities. The scatter plot in panel (b) provides a first empirical plausibility test for this reasoning, confirming that returns to education vary inversely with amenity expenditures, which is consistent with the assumption of nonhomothetic preferences.

Empirically, we estimate the second set of amenity budget shares for low-income households using a three-step procedure, broadly following the literature on budget share estimation (Fagiolo, Alessi, Barigozzi, \& Capasso, 2010, for an overview). First, we derive the MSA-level budget shares for implicit amenity expenditures of average households, $\bar{\sigma}^{z}$, using population weights to aggregate the BKP data up to the appropriate level of spatial resolution. Second, exploiting the link between returns to education and location-specific amenities illustrated above, we quantify the extent to which $\bar{\sigma}^{z}$ systematically varies with local incomes and returns to education, while controlling for a set of MSA-level characteristics. In the third and final step, we then use the coefficients from the second-stage regressions to predict amenity shares in each MSA for very low-income households under nonhomothetic preferences, $\sigma_{\gamma}^{z}$, applying the appropriate area income thresholds for very low-income households (50\% AMI).

Table 2 presents the coefficient estimates for the amenity share regressions for the second step of our estimation procedure outlined above. ${ }^{27}$ The parameters from the ordinary least squares (OLS) regression in column (1) confirm that the inverse relationship between amenity expenditures and returns to education first quantified in panel (b) of Figure 3 remains intact even after controlling for a series of MSA-level socioeconomic characteristics. Because amenity expenditure shares $\bar{\sigma}^{z}$ are bounded between 0 and 1, we use Papke and Wooldridge's (1996) quasi-likelihood method for regression models with a fractional dependent variable as a robustness check. Columns (2) and (3) report the coefficients and marginal effects for this specification. As for the OLS estimates, the coefficients of the generalized linear model (GLM) estimate are significant and all have the expected signs.

Table 3 summarizes the resulting distribution of our estimates for low-income amenity expenditure shares across MSAs. Column (1) presents the distribution of the budget share for implicit amenity for low-income households under the assumption of homothetic preferences, whereas column (2) shows the distribution of amenity shares under nonhomothetic preferences. By relaxing the assumption of unitary income elasticity across all households, the average for $\sigma_{\gamma}^{z}$ drops by over a quarter, implying that low-income households on average implicitly spend about $6.7 \%$ of their aftertax income on amenities, as opposed to almost $10 \%$ under preference homotheticity. Similarly, the highest estimated amenity share falls by more than half from an amenity budget share of almost $25 \%$ to around $12 \%$.

\subsection{Amenity expenditure shares with preference heterogeneity}

According to the BKP data for the year 2000, the average urban U.S. household implicitly forgoes $9.5 \%$ of after-tax income by enjoying a location-specific basket of nonmarket goods that encompasses a broad variety of geographic and climate characteristics, environmental externalities, local public goods, infrastructure characteristics, and cultural and urban amenities. The top panel of Table 4 shows that the income share of amenity expenditures for average households, $\bar{\sigma}^{z}$, varies significantly across regions, ranging from as little as $6.5 \%$ in the Midwest to as much as $14.6 \%$ for urban areas in the West. The middle panel of Table 4 reports that, assuming homothetic preferences, households with incomes low enough to qualify for the HCV program forgo on average just over $\$ 2,300$ of annual income to enjoy local amenities.

${ }^{27}$ As an intermediate stage to the second step of our estimation, we need to expand Black et al.'s (2009) sample size to match our own by producing out-ofsample predictions from a simple regression of returns to college as a function of house prices, the ratio of college-educated to high school-educated individuals, and a set of Census region dummies. 
While MSA-level amenity shares for HCV households under the assumption of homothetic preferences are identical to average shares by construction $\left(\sigma_{\gamma}^{z}=\bar{\sigma}^{z}\right)$, the weighted regional averages for $\sigma_{\gamma}^{z}$ in Table 4 diverge from $\bar{\sigma}^{z}$ due to differences in population weights as HCV participation rates vary across MSAs.

As we have seen, the strong assumption of unitary income elasticity for all goods under homothetic preferences is inconsistent with well-established evidence that suggests that income elasticities for many goods are different from one (e.g., Harmon, 1988; Hausman, Newey, \& Powell, 1995). If the regional cost of living indeed were independent of utility levels as homothetic preferences imply, policy public could safely ignore variations in the prices of local goods, in amenities, and in consumption bundles (Black, 2011). Allowing for nonhomothetic preference thus recognizes that the poor may spend a greater fraction of their income on housing than the average household, accounting for the concern that housing affordability pressures affect the poor more than the average household. The bottom panel of Table 4 reports our amenity expenditure share estimates for HCV households assuming nonhomothetic preferences. Consistent with the theoretical intuition established above, our estimates of average amenity expenditures are significantly lower than those derived under the assumption of homothetic preferences. If household preferences vary with incomes, we estimate that low-income households spend on average over $\$ 1,745$ or, on a population-weighted basis, $7.2 \%$ of annual income to enjoy local amenities. As a first quantification of the relationship between quality of life and housing subsidies, the last line of Table 4 suggests that, on average, the annual amenity consumption by low-income households accounts for over a third of the amount of annual subsidy payments.

While the evidence presented so far thus overwhelmingly suggests that low-income households have a lower marginal willingness to pay for living in high-amenity locations, the magnitude of this effect might not be overly important in practice. Indeed, Handbury (2016) shows that the extent to which assuming homotheticity biases estimates of spatial price indexes might matter less for low-income and middle-income households than it does for high-income households. $^{28}$

\subsection{The relationship between housing subsidies and amenity expenditures}

We turn now to a more systematic empirical exploration of cross-city HCV housing subsidies and amenity expenditures-another key element of this paper. For this analysis, Equation (3) provides the basic intuition for a linear specification of relative housing subsidies, $\tilde{s}_{j}$, as a function of relative amenity expenditures by low-income households in the MSA, $\tilde{z}_{j}$, and quality-adjusted wage differentials across metro areas, $\tilde{w}_{j}$, including a vector of MSA-level and regional controls $\boldsymbol{X}_{j}$ that account for local heterogeneity in terms of conventional population and housing characteristics such as, housing tenure choice, educational attainment, racial composition, and the age of the housing stock:

$$
\tilde{s}_{j}=\beta_{0}+\beta_{1} \tilde{z}_{j}+\beta_{2} \tilde{w}_{j}+X_{j} \gamma_{j}+\epsilon_{j}
$$

The theory developed in the previous section provides a rationale for including local wage differentials in the regression, given that in equilibrium, we expect the housing subsidies to be high in cities with large wage differentials. We estimate several specifications of Equation (4) using a variety of estimation approaches that are reported in Table 5. For all regressions, we report Huber-White robust standard errors unless noted otherwise. In columns (1)-(3), we present our baseline results from a series of OLS regressions that each include an additional set of control variables. The regression results from a minimally specified model, reported in the first column, produce estimates for the coefficients on amenity expenditure differentials, $\hat{\beta}_{1}$, and for the coefficient on wage differentials, $\hat{\beta}_{2}$, that are strongly significant and that have the predicted signs; above average housing subsidies systematically occur in metropolitan areas with above average amenity expenditures and with above average wages.

\footnotetext{
28 Specifically, Handbury (2016) suggests that a standard homothetic price index does a better job of predicting the distribution of costs across locations for low- and middle-income households than it does for high-income households, systematically underestimating the costs faced by high-income consumers in wealthy cities relative to poor cities.
} 


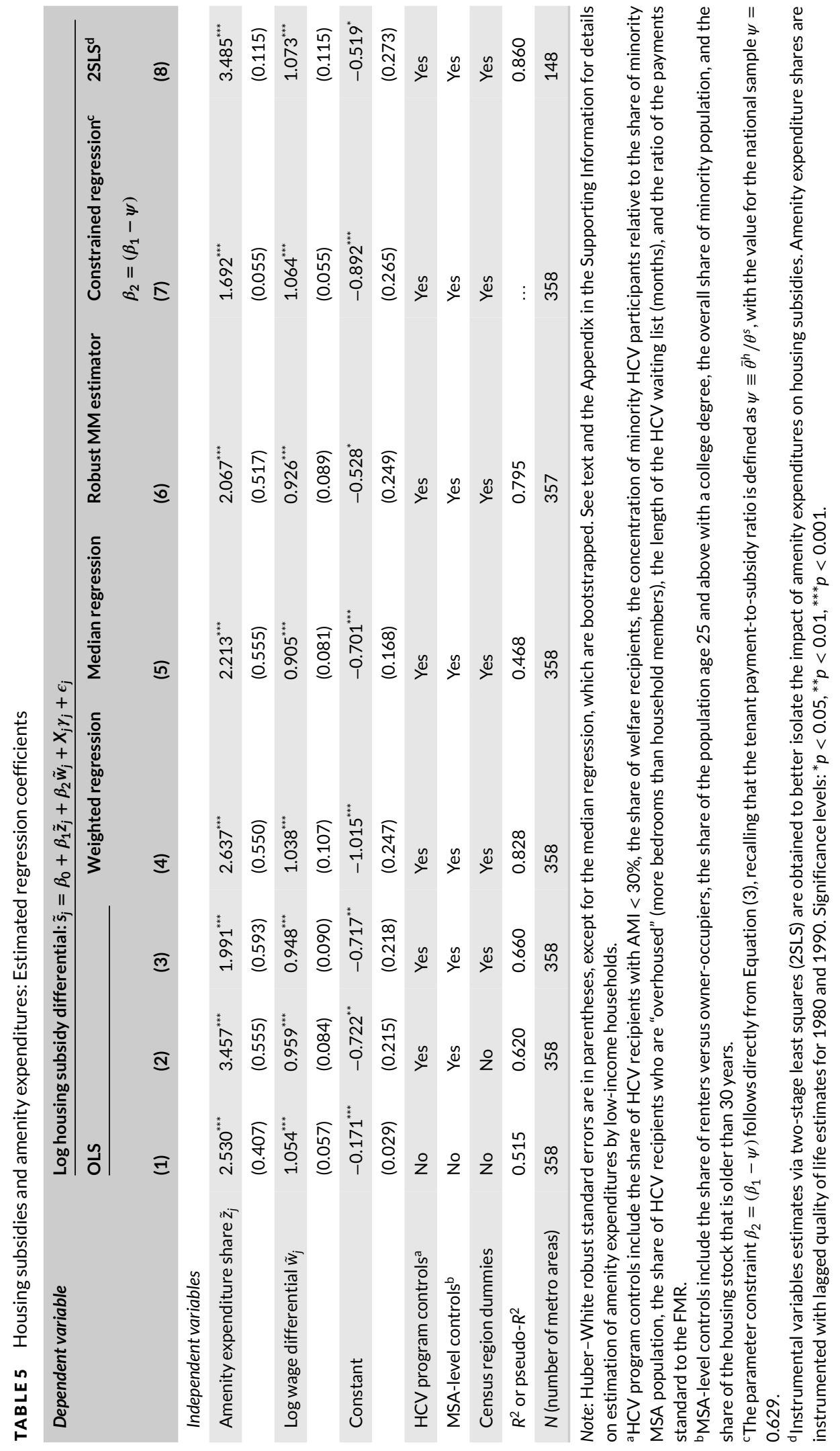


In order to address different sources of heterogeneity among metropolitan areas, the second and third columns of Table 5 report coefficient estimates from OLS regressions with an increasing number of controls. In column (2), we control for MSA-level differences in HCV program composition and program administration, including the share of HCV recipients with $\mathrm{AMI}$ of lower than $30 \%$, the share of welfare recipients, the concentration of minority HCV participants relative to the share of minority MSA population, the share of HCV recipients who are "overhoused" (more bedrooms than household members), the length of the HCV waiting list (months), and the ratio of the payments standard to the FMR in order account for administrative discretion in HCV implementation among local housing authorities. ${ }^{29}$ In addition, we also account for differences in local housing and labor market characteristics by controlling for the share of renters versus owner-occupiers, the share of the population age 25 and above with a college degree, the overall share of minority population, and the share of the housing stock that is older than 30 years. The specification in column (3) now adds Census region fixed effects to minimize the potential confounding impact of unobservables at the regional level. Irrespective of the number of controls included, the coefficients remain strongly significant and within an acceptable range. It is particularly worth highlighting that the estimates for $\beta_{2}$ stay within an order of magnitude that can be reconciled with the initial calibration of the model using the affordability condition implied in Equation (3).

\section{4 | Robustness checks}

For our baseline estimates, observations are unweighted by the metropolitan area size. This raises at least two immediate concerns; first, our results might be driven by small MSAs, and, second, housing subsidies in large metropolitan areas might be measured with more precision and, as such, carry more informational content about local housing and labor market conditions. To address these concerns, column (4) reports the results for a specification that weights by the population size of the metropolitan area. Our main result, if anything, is strengthened: relative housing subsidies are higher in locations where households implicitly spend comparatively more on amenities. In short, nicer places receive higher housing subsidies.

The remaining columns of Table 5 present additional robustness checks. Columns (5) and (6) investigate the extent to which our findings are due to outliers. First, we use a median regression with bootstrapped standard errors and then we use Jann's (2010) Stata implementation of robust regressions, which reduces the weight on outliers using the Huber objective function and critical values suggested by Yohai (1987). For both of these procedures, the results are quite similar and comparable to results from the OLS baseline. As a further robustness check, we use a constrained regression with parameter restrictions on $\beta_{1}$ and on $\beta_{2}$ that are implied by the affordability condition of spatial equilibrium. Specifically, the regression reported in column (7) uses the parameter constraint $\beta_{2}=\left(\beta_{1}-\psi\right)$, which follows directly from Equation (3), recalling that the tenant payment-to-subsidy (TTP-HAP) ratio is defined as $\psi \equiv \bar{r}^{\mathrm{max}} / \mathrm{s}^{*}=\bar{\theta}^{\mathrm{h}} / \theta^{\mathrm{s}}$, with the value for the national sample $\psi=0.629$ (see Table 1). Again, the coefficient estimates from the constrained regression remain within close range of the other estimates and, more importantly, are consistent with the predictions of our model. Overall, our results appear to provide persuasive evidence of substantial systematic amenity-driven differences in relative HCV housing subsidies across metropolitan areas in the United States.

Finally, we must address the concern that the amenity expenditure shares might be endogenous, primarily as a consequence of income sorting across metro areas. ${ }^{30}$ It is plausible that some of the impact of amenity expenditures on housing subsidies might stem from variation in amenity expenditures that is due to unobservable MSA-level income sorting, thus potentially rendering our OLS estimates biased and inconsistent. These endogeneity concerns provide the motivation for an instrumental variables (IVs) strategy to improve our identification of $\beta_{1}$ in Equation (4). For this purpose, we instrument amenity expenditure shares with lagged quality of life estimates for the years 1980 and 1990 that are obtained from Blomquist et al. (1988) and Deitz and Abel (2008), respectively. The basic intuition for this identification comes from the recognition that changes in the spatial variation of amenities occur over long horizons, andwhile partly being influenced by income sorting of households at the MSA level-the endogeneity concern arises from

\footnotetext{
${ }^{29} \mathrm{Cf}$. footnote 24 and Appendix B.4 in the Supporting Information.

30 We are grateful to one of the reviewers for highlighting this point.
} 
contemporaneous unobservables that are the result of the sorting process. Put differently, our IV strategy rests on the assumption that past indicators of quality of life are reasonable predictors of current household amenity expenditures, and are thus much less likely to be influenced by simultaneous income sorting dynamics. In our case, this means that we predict low-income amenity expenditure shares for the year 2000 using MSA-level quality of life metrics for the previous two decades $(1980,1990)$. Furthermore, given that our measure of amenity expenditure shares for low-income households, z̃, is estimated from the BKP data, there is the additional concern that our dependent variable of interest might be affected by measurement error. OLS estimates under a scenario of mismeasurement would be biased toward zero.

One might now ask whether one would expect our IV method to increase or decrease the estimates of amenity expenditure share on housing subsidy shares relative to simple OLS. While we can expect the results to be less positive to the extent that the IV strategy eliminates endogenous amenity expenditures that were accompanied by MSA-level income sorting, estimation-based mismeasurement in z̃ would induce OLS estimates to contain attenuation bias and the IV results should be larger. Ultimately, the relative incidence of endogeneity and measurement error will determine the relative size of the OLS and IV estimates. We obtain our IV estimates via two-stage least squares (2SLS) that are reported in column (8) of Table 5. After controlling for HCV program and MSA-level effects, we again find a strong positive association between amenity expenditure shares and housing subsidies. It is informative to compare the IV results with the OLS results from our preferred specifications in columns (4) and (5). The IV coefficients on low-income amenity expenditures are 25-45\% larger than the OLS coefficients. In line with our discussion above, we thus attribute the increase in coefficient size to measurement error in the amenity expenditure shares for low-income households. Using a standard interpretation of the coefficients, column (8) of Table 5 suggests that for each $10 \%$ that relative amenity expenditures exceed those in the average location, the corresponding HAPs exceed the national average by as much as a third (34.8\%). ${ }^{31}$ Again, we can confirm our theoretical prediction that HCV households living in the nicest places receive the largest housing subsidies, both in absolute and relative terms.

\section{5 | AMENITY-ADJUSTED HAPS AND POLICY REFORM}

Beyond their cyclical causes in the wake of the great housing bust, the secular decline of rent burdens among HCV households over the last decade or so is frequently viewed as a policy success among housing advocates. In 2010, about $22 \%$ of all households in the program spent more than $31 \%$ of their income on housing, significantly down from $38 \%$ in 2005 and 47\% in 2002 (McClure, 2005). Despite such progress, excessive rent burden ratios remain a significant concern as $20-25 \%$ of renter households experienced excessive burdens $-a$ trend that the recent uptick in national pressures on urban rental affordability has increased. As we have seen in Section 2.2 above, increases in local income inequality and their adverse impacts on social mobility might motivate a more active pursuit of HCV program participation as an objective of federal housing policy.

In a companion paper (Bieri \& Dawkins, 2016), we use the estimates of low-income amenity expenditure derived in this paper to demonstrate that broader program coverage could be achieved by reducing the amount of local indexing of wages and rents via an adjustment of HAPs by some portion of amenity compensating differentials. Specifically, we calculate that a series of amenity adjustments to assess different scenarios for reforms of the HCV program would reduce total HAP expenditures on existing program participants to approximately $\$ 4.7$ billion, freeing up $\$ 2.2$ billion that could cover, ceteris paribus, significantly more than half a million low-income households. Overall, this would boost national HCV program coverage by over $50 \%$. Although such a policy reform significantly reduces the program's overall rate of $\mathrm{HCV}$ rationing, average rent burdens would increase from 0.3 to just over 0.4 . A policy reform scenario of an

\footnotetext{
${ }^{31}$ Recalling from Equation (3) that $\hat{\beta}_{1}$ also represents a point estimate for (the inverse of) the subsidy-to-income ratio, $\theta^{s}$, we have an additional test for checking the plausibility of the results in Table 5. Our robustness estimates for the parameter on relative amenity expenditure shares in columns (4)-(8), $\beta_{1}^{(4)-(8)}$, can thus be interpreted as providing an upper bound $\hat{\beta}_{1}^{(7)}$ and a lower bound $\hat{\beta}_{1}^{(8)}$ on $\theta^{s}$; i.e., the implied values $\theta^{s}$ range from 0.287 to 0.591 . The unweighted sample average of our data $\bar{\theta}^{s}$ is 0.426 , almost exactly at the midpoint of that range.
} 
amenity-based reduction in subsidies to current HCV participants would level the playing field to the extent that it frees up money to provide vouchers to households with identical characteristics who had not previously been served. ${ }^{32}$ If reductions in the subsidies received by current participants are not politically feasible, the HCV program modification could phase in the new system by freezing subsidies at current levels and allowing amenity-adjusted MSA inflation differentials to erode real subsidy levels, an option that is discussed in Olsen (2007).

To further frame the relevance of amenity-adjusted housing subsidies within the larger context of federal housing policy, consider the broader connection between amenity-related compensating differentials and the spatial incidence of major housing subsidies in the United States. Housing affordability in the United States varies greatly with housing tenure choice and separate aspects of federal housing policy deal with the affordability of housing for homeowners and renters, respectively. Housing affordability for homeowners is largely addressed through indirect federal credit subsidies in the secondary mortgage market and through income tax expenditures, most notably the mortgage interest deduction (Poterba \& Sinai, 2008). By contrast, renter affordability programs involve direct subsidies to either housing supply (for example, via the Low-Income Housing Tax Credit program) or housing demand (via the HCV program).

As it turns out, the amenity-housing subsidy relationship identified in the previous section appears to hold irrespective of tenure choice. Panel (a) in Figure 4 provides an alternative illustration of our main empirical finding that (tenant-based) housing subsidies increase with relative amenity expenditures. By comparison, panel (b) plots average amenity expenditures against average income-tax-related housing subsidies to homeowners, confirming that highamenity areas also tend to receive the largest subsidies for owner-occupiers. ${ }^{33}$ Two additional insights emerge that are consistent with the work of Gyourko and Sinai (2003) and Sinai and Gyourko (2004). First, because housing subsidies offset a large component of local quality of life differentials, and quality of life is (weakly) increasing in city size, housing subsidies tend to be largest in the large metropolitan areas. Second, the geographic incidence of tenant-related housing subsidies by and large corresponds to the bicoastal pattern in the distribution of ordinary housing-related income tax benefits. For both homeowners and renters, there is thus a striking spatial skewness of housing subsidies whereby benefit flows increase with metropolitan quality of life. In terms of our previous discussion of indexing transfers to local prices, these spatial imbalances of subsidies are consistent with too much local indexing of housing-related transfers.

Indeed, Albouy and Hanson (2014) quantify the implicit cost-of-living adjustment in the federal tax code that occurs in the context of the tax benefits to housing. Specifically, they argue that such an adjustment may offset disincentives to live in high-wage areas if price levels are positively related to wages (high productivity locations), or magnify them if prices are negatively related to wages (high amenity locations). Consequently, tax benefits to housing will augment the implicit tax subsidy given to workers who accept lower pay to live in the most desirable areas. As Figure 4 illustrates, the annual intermetropolitan housing subsidy is proportional to the quality of life premium across all metropolitan areas, amounting to just under $50 \%$ of this premium on average. Taken together, this highlights that federal housing policy is spatially not neutral. Indeed, be it through the tax code for homeowners or HCV subsidies for renters, current housing policy favors coastal metros that enjoy above-average quality of life.

\section{6 | OUTLOOK}

The recent uptick in affordability pressures on the U.S. rental market has highlighted the inherent tensions in the objectives of federal low-income rental housing policy, i.e., ensuring affordability of low-income rental housing while providing access to high-amenity areas. In order to evaluate how this tension interacts with the locational efficiency implied

\footnotetext{
32 To put our scenario for amenity-adjusted subsidies into an economic context with current efforts for housing policy reform, consider that a recent proposal that targets net HAP overpayments because of administrative errors could have subsidized another 56,000 households with vouchers (GAO, 2012), merely a 10th of our proposed increase in coverage.

33 The relationship between amenity expenditure and housing subsidies to owner-occupiers remains stable across various specifications that involve a series of MSA-level controls, weighted observations, and variable transformations.
} 


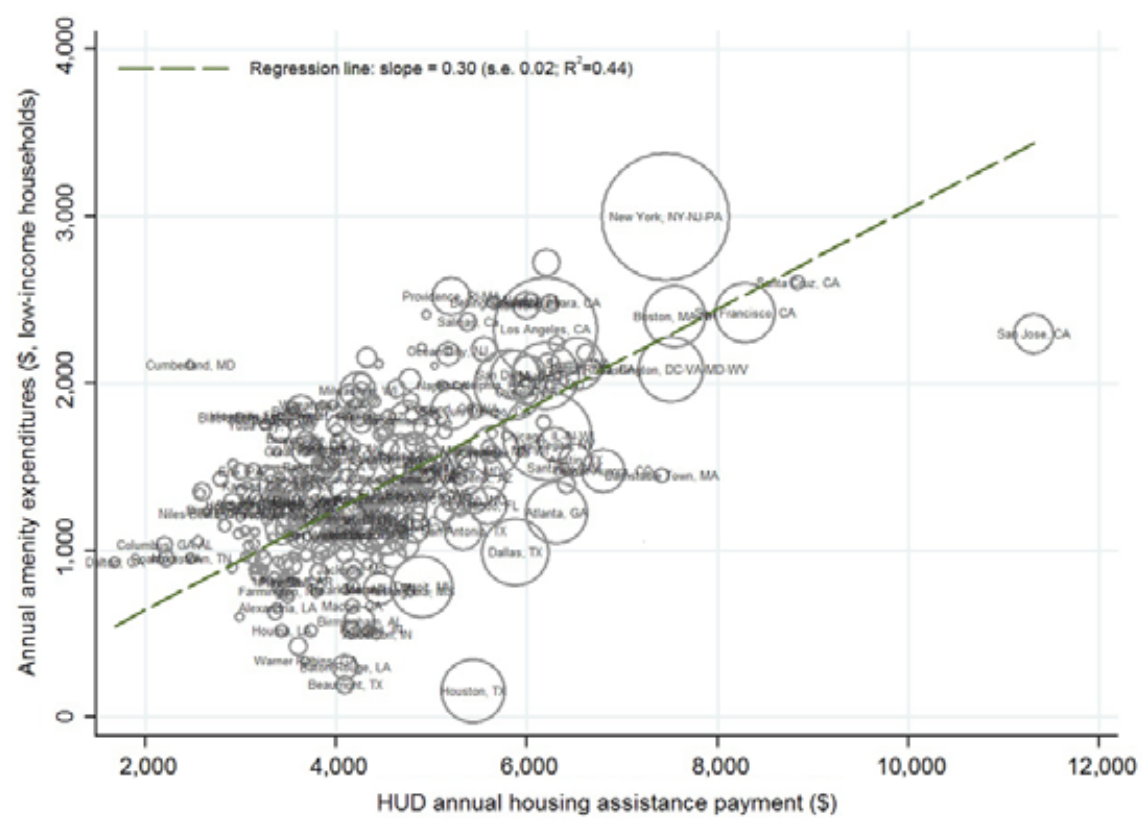

(a) Amenities and tenant-based housing subsidies

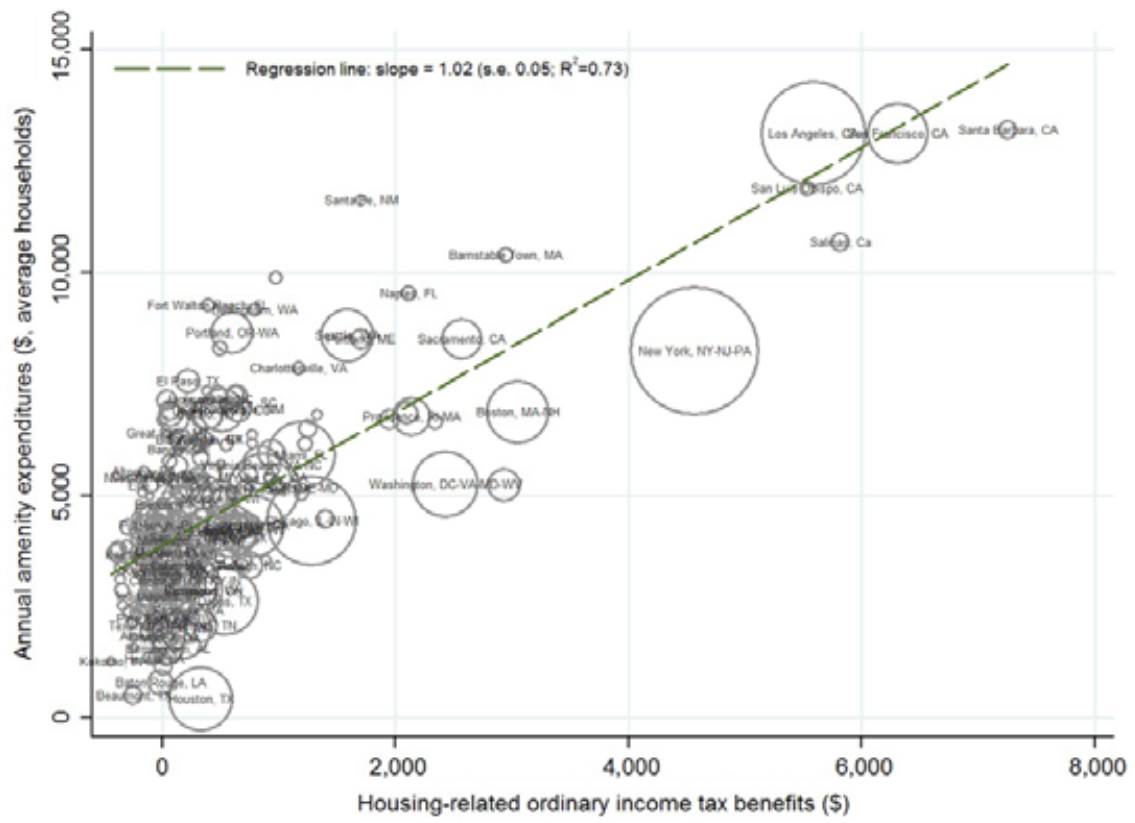

(b) Amenities and owner-based housing subsidies

FIGURE 4 Housing subsidies and amenity expenditures [Color figure can be viewed at wileyonlinelibrary.com] Notes: Panel (a) shows the spatial dispersion of tenant-based housing assistance payments and low-income amenity expenditures. Panel (b) illustrates how the spatial distribution of tax-related housing subsidies that accrue to owneroccupiers varies with household expenditures on local amenities. Housing-related ordinary tax benefits are derived from Gyourko and Sinai (2003) and amenity expenditures are from Bieri et al. (2014). See text and Appendix in the Supporting Information for details on estimation of amenity expenditures for very low-income households. 
by spatial equilibrium, we calculate housing subsidy payments for participants in the HCV program and demonstrate that these subsidies are significantly related to metropolitan quality-of-life differentials. Our empirical results confirm one of the key hypotheses of this paper, namely, that if housing affordability is operationalized as a national rent-toincome ratio, housing subsidy payments largely correspond to local differences in quality of life that arise from the wage and rent capitalization effects in the presence of localized amenity differentials. Our estimates show that a good third of HAPs correspond to the value of amenity consumption by HCV households. HAPs thus compensate households for living in nicer locations.

We also show that the spatial distribution of housing subsidies to very low-income households is highly skewed, favoring recipients who live in bigger coastal metropolitan areas where amenity-driven compensating differentials are large. This implies that the current HUD policy of using unadjusted FMRs as a basis for allocating housing assistance is most tilted toward larger metropolitan areas, where amenity-driven compensating differentials play a particularly important role. While the marginal utility of income may be higher in high-cost areas when household preferences are nonhomothetic, our results also suggest that the current indexing of HAPs to local prices might be too high form the perspective of locational and housing consumption efficiency. In this sense, our work is consistent with Kaplow's (1996) and Glaeser's (1998) findings that there is ample room for changes in government incentives that would increase transfers in low-cost areas and decrease transfers in high-cost areas. Indeed, despite increased geographical skill sorting across the most productive U.S. urban labor markets over the last three decades, there is less real wage inequality than nominal wage divergence appears to suggest (Moretti, 2012, 2013). However, more work is needed to understand the precise mechanisms that lie behind the current indexing of all housing-related transfer payments, not just HCV subsidies.

Yet, beyond efficiency considerations, we also argue that the tension between the people-based objectives of federal housing policy and the inherently place-based objectives of local land regulations might warrant a higher level of spatial indexing of HAPs that is implied by standard sorting models where changes in real wage inequality do not necessarily imply changes in well-being. At the same time, however, if federal housing policy leans against local supply-side drivers of housing cost pressures in the presence of excessive local land use restrictions, higher voucher indexing might encourage above-optimal rent seeking by landlords and local governments. Moreover, Hsieh and Moretti (2017) forcefully demonstrate that too few households live in productive superstar cities because of overly tight land use restrictions. In this context, HCV subsidies to households in high-amenity places could actually be a good thing, to the extent that housing supply is not perfectly inelastic and the subsidies thus spur some new housing construction in highly productive places. ${ }^{34}$

Spatial indexing considerations aside, one of the most compelling arguments for housing assistance reform is the fact that the current system creates a significant amount of horizontal inequity because of rationing, offering assistance to some, but not all, families with the same characteristics (Cutts \& Olsen, 2002). One prominent reform option is to render housing assistance an entitlement that would be administered by the IRS via a place-neutral tax credit (Olsen, 2008; Quigley, 2011; GAO, 2012). However, in the absence of the political feasibility of such far-reaching administrative changes to housing subsidies, a straightforward, budget-neutral alternative could be achieved by a simple reduction in subsidy levels in the HCV program, freeing up money to provide vouchers to additional households who want to participate, but cannot because of rationing. This paper suggests that one way to think about such a reform to the HCV program would involve amenity-adjusted HAPs that recognize metropolitan differences in housing prices and wages as a compensating differential reflecting households' valuation of nonmarket goods. To the extent that increasing HCV program participation among eligible low-income households is associated with higher levels of intergenerational mobility, this approach could help to ensure a more equitable and much broader distribution of HUD's affordable housing subsidies.

While recent work by Eriksen and Ross (2015) supports the notion that an increase in the supply of housing vouchers does not affect the overall price of rental housing, future research is needed to address the precise larger scale general equilibrium effects of such reforms. In any case, the expanding role of rental housing among an increasingly

${ }^{34}$ We are grateful to one of the reviewers for bringing this argument to our attention. 
diverse set of urban households-from the young, the elderly, the disabled, and low-wage working families to people in highly mobile professional sectors-is at odds with the fiscal reality of a share of U.S. federal funding for affordable housing that has been in secular decline since the 1980 s.

\section{ORCID}

David S. Bieri (iD http://orcid.org/0000-0002-4322-5950

\section{REFERENCES}

Albouy, D. Y., \& Hanson, A. R. (2014). Are houses too big or in the wrong place? Tax benefits to housing and inefficiencies in location and consumption. In R. A. Moffitt (Ed.), Tax policy and the economy (Vol. 28, pp. 63-96). Chicago: University of Chicago Press.

American Housing Act. (1949). Title V of Pub. L. 81-171, 63 Stat. 413-444 (Working paper). Washington, DC: United States Congress.

Bayer, P., Keohane, N., \& Timmins, C. (2009). Migration and hedonic valuation: The case of air quality. Journal of Environmental Economics and Management, 58(1), 1-14.

Beeson, P. E. (1991). Amenities and regional differences in returns to worker characteristics. Journal of Urban Economics, 30, 224-241.

Bieri, D. S., \& Dawkins, C. J. (2016). Quality of life, transportation cost, and federal housing assistance: Leveling the playing field. Housing Policy Debate, 26, 646-669.

Bieri, D. S., Kuminoff, N. V., \& Pope, J. C. (2014). National expenditures on local amenities (Working paper). University of Michigan, Arizona State University, and Brigham Young University.

Black, D. A. (2011). Four unresolved issues in the construction of regional cost-of-living indices (Unpublished mimeograph). University of Chicago, NORC, and IZA.

Black, D. A., Kolesnikova, N. A., \& Taylor, L. J. (2009). Earnings functions when wages and prices vary by location. Journal of Labor Economics, 27, 21-47.

Blomquist, G. C. (2006). Measuring quality of life. Blackwell companions to contemporary economics. In R. J. Arnott and D. P. Mcmillen (Eds.), A companion to urban economics (pp. 483-502). New York, NY: Blackwell Publishing.

Blomquist, G. C., Berger, M. C., \& Hoehn, J. P. (1988). New estimates of quality of life in urban areas. American Economic Review, 78, 89-107.

Chetty, R., Hendren, N., Kline, P., \& Saez, E. (2014). Where is the land of opportunity? The geography of intergenerational mobility in the United States. Quarterly Journal of Economics, 129, 1553-1623.

Collinson, R. A., \& Ganong, P. (2018). How do changes in housing voucher design affect rent and neighborhood quality? American Economic Journal: Economic Policy, 10, 62-89.

Cutts, A. C., \& Olsen, E. O. (2002). Are section 8 housing subsidies too high? Journal of Housing Economics, 11, $214-243$.

Davidoff, T. (2013). Supply elasticity and the housing cycle of the 2000s. Real Estate Economics, 41, 793-813.

Deitz, R., \& Abel, J. R. (2008). Have amenities become relatively more important than firm productivity advantages in metropolitan areas? (Staff Report No. 344). Buffalo, NY: Federal Reserve Bank of New York.

Diamond, R. (2016). The determinants and welfare implications of US workers' Diverging location choices by skill: $1980-2000$. American Economic Review, 106, 479-524.

Diamond, R. (2017). Housing supply elasticity and rent extraction by state and local governments. American Economic Journal: Economic Policy, 9, 74-111.

Edmiston, K. D. (2016). Residential rent affordability across U.S. metropolitan areas. Federal Reserve Bank of Kansas City Economic Review, 101, 5-27.

Eriksen, M. D., \& Ross, A. (2015). Housing vouchers and the price of rental housing. American Economic Journal: Economic Policy, 7, 154-176.

Fagiolo, G., Alessi, L., Barigozzi, M., \& Capasso, M. (2010). On the distributional properties of household consumption expenditures: The case of Italy. Empirical Economics, 38, 717-741.

Fisher, L., Pollakowski, H. O., \& Zabel, J. E. (2009). Amenity-based housing affordability indexes. Real Estate Economics, 37, 705746. 
Furman, J. (2015). Barriers to shared growth: The case of land use regulation and economic rents (Keynote address). Washington, DC: The Urban Institute.

Furman, J., \& Orszag, P. (2015). A firm-level perspective on the role of rents in the rise in inequality. Presentation at "a just society" Centennial Event in Honor of Joseph Stiglitz. New York: Columbia University.

GAO. (2012). Housing choice vouchers: Options exist to increase program efficiencies (Report to Congressional Requesters No. GAO-12-300). Washington, DC: United States Government Accountability Office.

Getsinger, L., Posey, L., MacDonald, G., \& Leopold, J. (2017). The housing affordability gap for extremely low-income renters in 2014. (Policy advisory group). Washington, DC: The Urban Institute.

Glaeser, E. L. (2017). Reforming land use regulations (Report in the Series on Market and Government Failures). Washington, DC: Brookings Center on Regulation and Markets.

Glaeser, E. L. (1998). Should transfer payments be indexed to local price levels? Regional Science and Urban Economics, 28, 1-20.

Glaeser, E. L., \& Gottlieb, J. D. (2008). The economics of place-making policies. Brookings Papers on Economic Activity, 39, 155253.

Glaeser, E. L., \& Gyourko, J. E. (2008). Rethinking federal housing policy: How to make housing plentiful and affordable. Washington, DC: The AEI Press.

Glaeser, E. L., Gyourko, J. E., \& Saks, R. E. (2005). Why is Manhattan so expensive? Regulation and the rise in housing prices. Journal of Law and Economics, 48, 331-369.

Greenwood, M. J., Hunt, G. L., Rickman, D. S., \& Treyz, G. I. (1991). Migration, regional equilibrium, and the estimation of compensating differentials. American Economic Review, 81, 1382-1390.

Gyourko, J., \& Molloy, R. (2015). Regulation and housing supply. In G. Duranton, J. V. Henderson, \& W. C. Strange (Eds.), Handbook of regional and urban economics (Vol. 5, Chapter 19, pp. 1289-1337). Amsterdam and Oxford: Elsevier Science.

Gyourko, J. E., Kahn, M. E., \& Tracy, J. (1999). Quality of life and environmental comparisons. In G. Duranton, J. V. Henderson, \& W. C. Strange (Eds.), Handbook of regional and urban economics: Applied urban economics, Vol. 3 of Handbooks in Economics (pp. 1413-1454). Amsterdam: North-Holland.

Gyourko, J. E., \& Sinai, T. M. (2003). The spatial distribution of housing-related ordinary income tax benefits. Real Estate Economics, 31, 527-575.

Handbury, J. (2016). Are poor cities cheap for everyone? Non-homotheticity and the cost of living across U.S. cities (Research Paper No. 71). Philadelphia, PA: Wharton School, University of Pennsylvania.

Harmon, O. R. (1988). The income elasticity of demand for single-family owner-occupied housing: An empirical reconciliation. Journal of Urban Economics, 24, 173-185.

Hausman, J. A., Newey, W. K., \& Powell, J. L. (1995). Nonlinear errors in variables: Estimation of some Engel curves. Journal of Econometrics, 65, 205-233.

Hilber, C. A. L., Lyytikäinen, T., \& Vermeulen, W. (2011). Capitalization of central government grants into local house prices: Panel data evidence from England. Regional Science and Urban Economics, 44, 394-406.

Hilber, C. A. L., \& Robert-Nicoud, F. (2013). On the origins of land use regulations: Theory and evidence from us metro areas. Journal of Urban Economics, 75, 29-43.

Hsieh, C. T., \& Moretti, E. (2017). Housing constraints and spatial misallocation (Working Paper No. 21154). Cambridge, MA: National Bureau of Economic Research.

HUD. (2001). Housing choice voucher program guidebook (Working paper). Washington, DC: U.S. Department of Housing and Urban Development.

Ihlanfeldt, K. R. (2007). The effect of land use regulation on housing and land prices. Journal of Urban Economics, 61, 420-435.

Ikeda, S., \& Washington, E. (2015). How land-use regulation undermines affordable housing (Mercatus research). Arlington, VA: Mercatus Center, George Mason University.

Jann, B. (2010). robreg: Stata module providing robust regression estimators (Technical manual). ETH Zürich.

JCHS. (2015). America's rental housing: Expanding options for a growing and diverse demand (Working paper). Joint Center for Housing Studies of Harvard University.

Jorgenson, D. W., \& Slesnick, D. T. (1999). Indexing government programs for changes in the cost of living. Journal of Business and Economic Statistics, 17, 170-181.

Kaplow, L. (1996). Regional cost-of-living adjustments in tax-transfer schemes. Tax Law Review, 51, 175-198.

Kline, P., \& Moretti, E. (2013). Place based policies with unemployment. American Economic Review, 103, $238-243$. 
Kline, P., \& Moretti, E. (2014). People, places and public policy: Some simple welfare economics of local economic development programs. Annual Review of Economics, 6, 629-662.

Knoll, M. S., \& Griffith, T. D. (2003). Taxing sunny days: Adjusting taxes for regional living costs and amenities. Harvard Law Review, 116, 987-1025.

Kuminoff, N. V., Smith, V. K., \& Timmins, C. (2013). The new economics for equilibrium sorting and policy evaluation using housing markets. Journal of Economic Literature, 51, 100-1062.

Lambiri, D., Biagi, B., \& Royuela, V. (2007). Quality-of-life in the economic and urban economic literature. Social Indicators Research, 84, 1-25.

Levine, J. (2006). Zoned out: Regulation, markets, and choices in transportation and metropolitan land-use. Washington, DC: Resources for the Future.

McClure, K. (2005). Rent burden in the housing choice voucher program. Cityscape: A Journal of Policy Development and Research, 8, 5-20.

Metcalf, G. (2018). Sand castles before the tide? Affordable housing in expensive cities. Journal of Economic Perspectives, 32(1), 59-80.

Moretti, E. (2012). The new geography of jobs. New York, NY: Houghton Mifflin Harcourt.

Moretti, E. (2013). Real wage inequality. American Economic Journal: Applied Economics, 5, 65-103.

NLIHC. (2017a). The gap: A shortage of affordable homes (Working paper). Washington, DC: National Low Income Housing Coalition.

NLIHC. (2017b). Out of reach 2017: The high cost of housing (Annual report). Washington, DC: National Low Income Housing Coalition.

Olsen, E. O. (2008). Getting more from low-income housing assistance (Hamilton Project Discussion Paper No. 2008-13). Washington, DC: Brookings Institution.

Olsen, E. O. (2003). Housing programs for low-income households. In R. A. Moffitt (Ed.). Means-tested transfer programs in the United States(pp. 365-441). Chicago: University of Chicago Press.

Olsen, E. O. (2007). A primer on U.S. housing markets and housing policy, green, Richard K., Malpezzi, Stephen. (2003). Washington, DC: Urban Institute Press. Regional Science and Urban Economics, 37, 618-624.

Olsen, E. O., \& Zabel, J. E. (2015). US housing policy. In G. Duranton, J. V. Henderson, \& W. C. Strange (Eds.), Handbook of regional and urban economics (Vol. 5, Chapter 14, pp. 887-986). Amsterdam and Oxford: Elsevier Science.

Ortalo-Magné, F., \& Prat, A. (2014). On the political economy of urban growth: Homeownership versus affordability. American Economic Journal: Microeconomics, 6, 154-181.

Papke, L. E., \& Wooldridge, J. (1996). Econometric methods for fractional response variables with an application to 401(k) plan participation rates. Journal of Applied Econometrics, 11, 619-632.

Partridge, M. D., Rickman, D. S., Olfert, M. R., \& Tan, Y. (2015). When spatial equilibrium fails: Is place-based policy second best? Regional Studies, 49, 1303-1325.

Poterba, J., \& Sinai, T. M. (2008). Tax expenditures for owner-occupied housing: Deductions for property taxes and mortgage interest and the exclusion of imputed rental income. American Economic Review, 98, 8489.

Quigley, J. M. (2011). Rental housing assistance. Cityscape: A Journal of Policy Development and Research, 13, 147-158.

Quigley, J. M., \& Raphael, S. (2004). Is housing unaffordable? Why isn't it more affordable?Journal of Economic Perspectives, 18(1), 191-214.

Roback, J. (1982). Wages, rents, and the quality of life. Journal of Political Economy, 90, 1257-1278.

Roback, J. (1988). Wages, rents, and amenities: Differences among workers and regions. Economic Inquiry, 26, 23-41.

Rosen, S. (1979). Wage-based indexes of urban quality of life. In M. R. Straszheim \& P. M. Mieszkowski (Eds.), Current issues in urban economics (pp. 74-104). Baltimore, MD: Johns Hopkins University Press.

Saiz, A. (2010). The geographic determinants of housing supply. Quarterly Journal of Economics, 125, 1253-1296.

Schwartz, A. E., Gould Ellen, I., Voicu, I., \& Schill, M. H. (2005). The external effects of place-based subsidized housing. Regional Science and Urban Economics, 36, 679-707.

Sinai, T. M., \& Gyourko, J. E. (2004). The (un)changing geographical distribution of housing tax benefits: 1980 to 2000 . In J. Poterba (Ed.), Tax policy and the economy (Vol. 18, 175-208). Cambridge, MA: MIT Press. 
Turner, M. A., Haughwout, A., \& van der Klaauw, W. (2014). Land use regulation and welfare. Econometrica, 82, $1341-1403$.

Yohai, V. J. (1987). High breakdown-point and high efficiency robust estimates for regression. Annals of Statistics, 15, 642656.

\section{SUPPORTING INFORMATION}

Additional supporting information may be found online in the Supporting Information section at the end of the article.

How to cite this article: Bieri DS, Dawkins CJ. Amenities, affordability, and housing vouchers. J Regional Sci. 2019;59:56-82. https://doi.org/10.1111/jors.12400 